\title{
'A most public spirited and unselfish man'1: the career and contribution of Colonel Maurice Moore, 1854-1939
}

\author{
DAITHÍ Ó CORRÁIN \\ (St Patrick's College, Drumcondra)
}

Despite his lengthy and varied career, Maurice Moore has faded from history. His has not been a life story repeatedly retold like those of prominent figures during the Irish Revolution or indeed like his older brother, George, the distinguished novelist. ${ }^{2}$ Though included in the Dictionary of Irish Biography and frequently referred to in the context of the Irish Volunteers, Moore's activities and interests have not received an in-depth appraisal. ${ }^{3}$ The present account, which is based on his personal papers, aims to rectify this and to rescue him from relative obscurity. By professional training a soldier, Moore was decorated for his service and rose to the rank of lieutenant-colonel of the Connaught Rangers. Yet he was an unconventional army officer. As described in section 1 below, Moore was highly critical of British methods to undermine Boer resolve during the Second South African War; this generated significant public controversy. The efforts by the Boers to achieve independence and the establishment of the Union of South Africa as a dominion in 1910 left a lasting impression on Moore and influenced his thinking on Irish self-government. His familiarity with the country and Jan Smuts were central to Moore's appointment by Dáil Éireann as secret envoy to South Africa in April

\footnotetext{
1 'Reminiscences by Diarmid Coffey' (NLI, Coffey and Chenevix Trench papers, MS 46,315/5). An early version of this article was presented at the 18 th Conference of Irish Historians in Britain at the University of York, 15 Sept. 2012 under the title 'Idiosyncratic patriot or amenable old duffer?: the unsung life of Colonel Maurice Moore'.

${ }^{2}$ These include Humbert Wolfe, George Moore (London, 1931); Joseph Hone, The life of George Moore (London, 1936); Janet Egleson Dunleavy, George Moore: the artist's vision, the storyteller's art (Lewisburg, 1973); Tony Gray, A peculiar man: a life of George Moore (London, 1996); Adrian Frazier, George Moore, 1852-1933 (New Haven and London, 2000); Robert Welch, 'Moore, George Augustus', in James McGuire and James Quinn (eds), Dictionary of Irish Biography (DIB) (Cambridge, 2009) [http://dib.cambridge.org/viewReadPage.do?articleId=a5930 accessed 28 Apr. 2014]. All make passing references to Maurice Moore.

${ }^{3}$ Marie Coleman, 'Moore, Maurice George', in DIB [http://dib.cambridge.org/ viewReadPage.do? articleId=a5942, accessed 7 Apr. 2014]. The only other significant treatment of Moore's career is Joseph Hone, The Moores of Moore Hall (London, 1939) which charts the fortunes of the family from 1790 until 1937 . Hone had access to the papers of George Moore and Maurice Moore and also drew on the reminiscences of Maurice Moore, son of the subject of this article. Colonel Maurice Moore's papers are in the care of the National Library of Ireland.
} 
1921 to put the Irish case before the South African premier. P .J. Little, a fellow Dáil envoy during the War of Independence, believed that Moore played a 'very important part in getting Smuts to raise the Irish question' at the Imperial Conference in 1921 and help bring about the Anglo-Irish truce. ${ }^{4}$ This little known, but pivotal, episode is discussed in section 7.

Although Moore used the title colonel in retirement, there was no doubting his nationalist impulse and the sincerity of his patriotism; as one contemporary put it, "the veneer of the British military caste never quite cover[ed] the Catholic and nationalist Irishman underneath'. ${ }^{5}$ Two significant influences may be identified. The first was Moore's family lineage, reputation and tradition. His granduncle, John, participated in the 1798 rebellion and was president of the government of Connaught. ${ }^{6}$ Moore's father, George Henry, was first elected MP for Mayo in 1847 and subsequently took a leading part in opposing the Ecclesiastical Titles Act and in formulating the policy of independent opposition among Irish MPs during the early 1850s. He 'flirted with Fenianism' in the mid-1860s and in 1868 contested the general election on a platform of tenant right and amnesty for Fenian prisoners. ${ }^{7}$ George Henry was also one of the principal architects of the Home Government Association, which demanded Irish self-government, though he died in April 1870, a month before the association was formally established. The family name together with George Henry's achievements as a jockey and horse breeder, landowner and nationalist politician bestowed on his son an element of name recognition in many influential circles. Two other family inheritances are worthy of mention: Moore's interest in Irish history and his skill with a pen. ${ }^{8}$ The second major influence on Moore was his involvement in the Gaelic League, which is addressed in section 2. A confidante of Douglas Hyde, the pioneering Gaelic scholar and founder of the Gaelic League, Moore shared the latter's belief in the intrinsic link between language and national identity. The inclusive nature of the League, with its attempt to transcend religious and political differences, also pleased Moore, who was an

\footnotetext{
${ }^{4}$ Witness statement of P. J. Little (Bureau of Military History (hereafter BMH), Witness Statement (hereafter WS) 1,769, 80).

${ }^{5}$ Unpublished memoir by Edward MacLysaght, 'Master of none', c. 1951, chapter 6 (NLI, Edward MacLysaght papers, MS 4,750).

${ }^{6}$ See Sheila Mulloy, 'Moore, John', in DIB [http://dib.cambridge.org/viewReadPage. do? articleId=a5938, accessed 28 April 2014]; Hone, Moores of Moore Hall, 33-45.

${ }^{7}$ Owen McGee, 'Moore, George Henry', in DIB [http://dib.cambridge.org/ viewReadPage.do?articleId=a5931, accessed 28 April 2014].

${ }^{8}$ His grandfather George was a historian. Three of his brothers - George (a writer), Augustus (a journalist) and Julian (an academic) - earned a living with their pen.
} 
active apostle of the League at a local and national level between 1902 and 1911. This proved a transformative experience and is key to understanding his subsequent participation in the Irish Volunteers. Moore's active involvement in the Gaelic League came to an end in 1911 when he moved his family to Brussels following the breakdown of his relationship with his brother George, ostensibly over religion and land. This dispute has been addressed by all of the novelist's biographers, but section 3 of this essay presents the matter from Maurice's perspective.

Sections 4 and 5 discuss Moore's involvement in the Irish Volunteers and, following the split in that organization in September 1914, his contribution to the Redmondite National Volunteers. His contribution as an energetic organizer and member of the provisional committee was more decisive, particularly in the early months of 1914 , than has generally been realized. The soldier's sense of duty saw Moore remain loyal to the Redmondite side, though not without significant misgivings or indeed a desire to see the two Volunteer organizations unified. Following the 1916 Rising, Moore became increasingly estranged from the Irish Parliamentary Party (IPP) and when efforts to revive the National Volunteers were thwarted he and a section of the National Volunteers reunited with the Irish Volunteers in 1917. This is treated in section 6 along with Moore's contributions on various public matters, from seeking a reprieve for Roger Casement to floating a scheme of dominion self-government. These attest to his remarkable versatility and vigour. Neither declined as the years advanced. Moore supported the Anglo-Irish Treaty in 1921 and served as a Free State senator in the 1920s and 1930s. As shown in section 8, his spirited opposition to the payment of land annuities and the Boundary Commission fiasco occupied his later years. Although arguably a second rank activist, Moore's life story casts valuable light on important episodes in twentieth-century Irish history in which he rendered quietly impressive service. Often unconventional, never afraid of controversy, and ever genial, Moore displayed a remarkable mutability in terms of the range of his public interests, but he was not inconsistent. The underpinning motivation throughout his long career was a deep-seated sense of patriotism and service in the interest of Ireland.

\section{Connaught Ranger, 1874-1906}

The second son ${ }^{9}$ of George Henry Moore, Maurice George Moore

\footnotetext{
${ }^{9}$ George (b. 1852), Maurice (b. 1854), Augustus (b. 1856), Nina (b. 1858) and Julian (b. 1867).
} 
was born at Moore Hall, the family's Georgian mansion, in Ballyglass, County Mayo in 1854. Like his father and brothers, Maurice was educated at St Mary's College Oscott, near Birmingham, the school attached to the seminary of the archdiocese of Birmingham, which played a prominent part in the nineteenth-century revival of English Catholicism. George Henry wanted both of his older sons to join the army. ${ }^{10}$ Only Maurice complied, entering Sandhurst. On first consideration, this might seem an unusual choice for the son of an Irish nationalist MP. But there was a well-established tradition of better off families, typically the landed Anglo-Irish, sending their children to English schools and thence into the armed services. Irishmen constituted 17.5 per cent of British army officers in 1878. ${ }^{11}$ Moore's thirty-two year career in the British army began when he was gazetted a sub-lieutenant (the equivalent of a second-lieutenant) in the land forces on 13 June 1874, having achieved an impressive ninth place in the examinations for first appointments to the cavalry and infantry. ${ }^{12}$ Two years later he was promoted to lieutenant in the 88th Foot, subsequently the 1st Battalion, The Connaught Rangers. ${ }^{13}$ Not lacking in physical courage, Moore was mentioned in despatches during the South African Kaffir and Zulu wars of the late 1870s and was awarded a medal and clasp. Between 1879 and 1891 he served in India and was promoted to the rank of major in February $1883 .{ }^{14}$ This service was punctuated by periods of leave in Mayo during which, among other matters, Major Moore pursued his romantic interests. In 1889 he married Evelyn Handcock of Carrowntryla estate, near Dunmore, County Galway. The couple had two sons: Maurice and Ulick, who were known within the family as Rory and Toby. ${ }^{15}$

The 1st Battalion, Connaught Rangers was on home service in Ireland between 1893 and November 1899 when it was sent to Natal under Major-General Fitzroy Hart to fight in the second Boer War. Moore was present at the battles of Colenso (15 December 1899), Spion Kop (26 January 1900) and Vaal Krantz (5-7 February 1900) -

\footnotetext{
${ }^{10}$ Gray, A peculiar man, 45; Frazier, George Moore, 20.

${ }^{11}$ E.M. Spiers, 'Army organisation and society in the nineteenth century', in Thomas Bartlett and Keith Jeffery (eds), A military history of Ireland (Cambridge, 1996), 341.

${ }^{12}$ Warrant of appointment; "Table showing the marks obtained by the candidates for first appointment to the Cavalry and Infantry who were examined under the directions of the Civil Service Commissioners at Burlington Gardens on the 17th April 1874 and subsequent days' (NLI, Maurice Moore papers, MS 10,576).

${ }^{13}$ On 30 June 1881 the 88th Regiment of Foot (Connaught Rangers) (which formed the 1st Battalion) and the 94th Regiment of Foot (which formed the 2nd Battalion) ceased to be regiments in themselves and were amalgamated under the regimental title The Connaught Rangers.

${ }^{14}$ Coleman, 'Moore, Maurice George'.

${ }^{15}$ Ibid.
} 
all British reverses - prior to the relief of Ladysmith on 28 February. While in South Africa, due to a shortage of mounted men, Moore formed half of the Connaught Rangers into a mounted column, which operated successfully in Cape Colony and the Orange River Colony from May 1900 until the end of the war. He was awarded the C.B. (Companion of the Order of Bath) in December 1902 for his services, which included command of the 1st Battalion from 6 December 1900 until the end of hostilities. ${ }^{16}$

Moore was, however, appalled at the methods employed by Horatio Herbert Kitchener, commander-in-chief of the British forces. In letters to his brother George, who detested the war, Moore described the harsh treatment of Boer civilians, the recourse to concentration camps and orders to burn farms. George leaked this information to W. T. Stead, editor of the Review of Reviews, who was a fervent opponent of the war, and in this way anonymous excerpts from Moore's letters were circulated in England. On 22 December 1900, under the heading 'Letters from the Front', the Tablet reprinted one such letter, which had previously been published in The Stonyhurst Magazine. ${ }^{17}$ This prompted a heated series of letters to the editor in the course of which Bishop Edward O'Dwyer of Limerick branded the account 'sickening in its cowardice and brutality', and rebuked the editor for forgetting 'the very elements of Catholic principles and Christian feeling as to publish, evidently with exultation, so abominable a crime'.$^{18}$ The controversy did not end there. With George Moore's connivance, a further letter was published anonymously in the Freeman's Journal on 15 January 1901 in which Moore related secret orders from Kitchener that no prisoners be taken if General Christiaan de Wet's guerrilla forces were surrounded, and made clear his repugnance at such tactics. ${ }^{19}$ Extracts of the letter reappeared in the London Times the following day; it was republished in South Africa, as a result of which four editors in Cape Colony were imprisoned; and it was the subject of a parliamentary question. ${ }^{20} \mathrm{Had}$ its authorship been revealed, Moore would certainly have been court martialled and if found guilty shot

\footnotetext{
${ }^{16}$ Albert W. Woods (Garter, Order of the Bath) to Moore, 5 Dec. 1902 (NLI, Moore papers, MS 10,561/39). For a detailed account of operations under Moore's command see H. F. N. Jourdain and Edward Fraser, The Connaught Rangers, Vol. 1: 1st Battalion, formerly 88th Foot (London, 1924), 324-406.

${ }^{17}$ Tablet, 22 Dec. 1900, 977-8.

${ }^{18}$ Tablet, 5 Jan. 1901, 21. For criticism of the bishop, see letter by H.I.D. Ryder to the editor of the Tablet, 12 Jan. 1901, 61.

${ }^{19}$ Freeman's Journal, 15 Jan. 1901

${ }^{20}$ Times, 16 Jan. 1901; Albert Cartright to Moore, 2 July 1924 (NLI, Moore papers, MS 10,561/2). Cartright was one of the prosecuted editors, having published the letter in the South African News; Hansard 4 (Commons), 89, col. 1180 (26 Feb. 1901).
} 
or imprisoned. The episode demonstrates his moral courage and sense of rectitude. Twenty years later he admitted to Jan Smuts: 'I suffered in mind and conscience for doing what I knew was wrong, and for which I owed and tried to make some small reparation. ${ }^{21}$ The example of the Boers informed Moore's views on the subject of Irish self-government but he always retained an imperial frame of reference and, ultimately, favoured a dominion form of Irish selfrule. After the South African war Moore was formally promoted to the command of his battalion until he relinquished the role on his departure from the military on 16 July $1906 .{ }^{22}$ He may have departed the army but Moore never retired. He turned his focus to Ireland and embarked on a vigorous but unplanned 'second career'.

\section{Gaelic Leaguer, 1902-11}

Even before his retirement from the army Moore was strongly attracted to the Gaelic League and the co-operative movement. Both took root in the 1890s when Moore was on home service, during which time he was stationed in Athlone and Castlebar. His 'intelligent assistance' to Burriscarra Co-operative Agricultural Society in Mayo from its inception in 1898 until his resignation in 1912 was greatly praised by the society. ${ }^{23}$ Moore's enthusiasm for the Gaelic League was more problematic but it was not unusual. The organization drew to its ranks men and women of all ages and from all socio-economic backgrounds. ${ }^{24}$ Moore reputedly taught himself Irish while in South Africa and practised with Irish-speaking soldiers of the Connaught Rangers. He enjoyed a close friendship with Douglas Hyde. It is unclear when the relationship was established but they corresponded regularly, and mostly in English, from 1899 onwards. The affection between them was manifest in early 1908 as Hyde made a slow recovery from a serious bout of pneumonia. Moore implored him not to 'take any part in public business for a long time. You could do no greater harm to your country than to run any risk'. ${ }^{25}$ Moore and Hyde also socialised on occasion. For instance, they attended the Mayo County Feis in April 1903. Given the literary circles in which he moved, Hyde also knew George

\footnotetext{
${ }^{21}$ Moore to Jan Smuts, c. 20 Aug. 1921 (NLI, Moore papers, MS 10,581).

${ }^{22}$ Times, 17 July 1906; Jourdain and Fraser, Connaught Rangers, 406, 411.

${ }^{23}$ Report of the assistant registrar of friendly societies for Ireland to the chief registrar of friendly societies for the year ending 31 Dec. 1898, 65; Rev. M. O'Connell PP (chairman Burriscarra Co-operative Agricultural Society) and P. Prendergast (secretary) to Moore, 24 Mar. 1912 (NLI, Moore papers, MS 10,561/31A).

${ }^{24}$ See Timothy McMahon, Grand opportunity: the Gaelic revival and Irish society, 1893-1910 (Syracuse, 2008), 85-126.

${ }^{25}$ Moore to Hyde, 5 Jan. [1908] (NLI, Douglas Hyde papers, MS 21,098/1).
} 
Moore, who for a time shared his soldier brother's interest in the language movement. The première of Hyde's second play in Irish, An Tincéar agus an tSidheóg, took place in George Moore's garden at 4 Ely Place, Dublin in May 1902. ${ }^{26}$ Maurice supported the twopronged Gaelic League strategy of promoting the teaching of Irish in the schools and obtaining the support of the Catholic Church, which Hyde believed was indispensable to the League's prospects of success. ${ }^{27}$ In his famous presidential address to the National Literary Society in 1892 - 'the necessity for de-anglicising Ireland' - Hyde expounded on the vital relationship between national identity and language revival. Moore shared this view. His occasional writings on the language and its history echoed Hyde's sentiments. For instance, Moore told one gathering that 'we must make ourselves Irish in speech as well as in name; real Irishmen not anglicised Irishmen as unfortunately most of us are'. ${ }^{28} \mathrm{He}$ also frequently evoked the revival of minority languages in Bohemia, Finland, Hungary and Frenchspeaking Canada, which he visited in 1910 and which appears to have made a lasting impression on him. ${ }^{29}$

When he returned to Ireland in late 1902 Moore assisted with the establishment of eight evening schools, including one at Moore Hall, which taught Irish language and Irish history. ${ }^{30}$ Hyde was 'perfectly delighted' by this 'astonishing success', and confidently suggested that 'we will have all central Mayo speaking Irish in ten years' time ... the curates will be parish priests in their turn and managers of schools, and the most of them have a real grip of Gaelic League doctrine'. ${ }^{31}$ The evening schools were taught by primary school teachers, and since their fees were paid by the National Board Hyde was keen to make fuller use of the opportunity this presented. 'The ball is actually at our foot', he wrote to Moore, 'if we were men enough to kick it. ${ }^{32}$ However, the National Board refused to sanction

\footnotetext{
${ }^{26}$ Janet Egleson and Gareth W. Dunleavy, Douglas Hyde: a maker of modern Ireland (Berkeley, 1991), 221-2.

${ }^{27}$ Ibid., 301.

${ }^{28}$ Untitled address by Moore, n.d. (NLI, Moore papers, MS 10,571/2).

${ }^{29}$ See, for example, Moore's comments on Bohemia in a letter to the editor of the Connaught Telegraph, 30 Apr. 1910 (published on 7 May 1910) and an article on bilingual Canada in An Claidheamh Soluis, 22 Apr. 1911. Many of the same ideas are articulated in a five-part series by Moore, 'Language and Nationality' in $A n$ tEaglaiseach Gaedhealach: the Gaelic Churchman, 3:12 (May 1922), 4:1 (June 1922), 4:2 (July 1922), 4:3 (Aug-Sept. 1922) and 4:4 (Oct. 1922). The latter was the organ of the Church of Ireland body Cumann Gaelach na hEaglaise.

${ }^{30}$ Under the auspices of the National Board of Education, evening schools catered for those over the age of fourteen, see The sixty-ninth report of the Commissioners of National Education in Ireland for the year 1902 (1903) Cd. 1679, 19.

${ }^{31}$ Hyde to Moore, 26 Oct. 1902 (NLI, Moore papers, MS 10,561/21).

${ }^{32}$ Hyde to Moore, 5 Nov. 1902, ibid.
} 
the Moore Hall evening school in December 1902 and subsequent appeals were rejected on the grounds that English should be taught to illiterate students and that primary teachers should not teach in more than one evening school, even on different days. ${ }^{33}$ Moore was furious. In a strongly worded letter to the Freeman's Journal, Moore alleged that due to its 'narrow anti-Irish prejudices' the Board had arbitrarily altered the rules. He called for 'vigour and determination to put down the anti-national Board' should endorsement remain unforthcoming. ${ }^{34}$ Moore's intervention was praised by Hyde as a 'telling sledge-hammer letter ... There is nothing bigots like [Anthony] Traill fear more than exposure'. ${ }^{35}$ This was a reference to the Trinity College don who was a commissioner and, subsequently, provost of Trinity from 1904. Moore contemplated mounting a legal challenge but, with insufficient funds, he and Hyde opted instead to bring the matter to the attention of John Redmond, leader of the IPP, fully intent on engaging in public controversy should this be necessary. ${ }^{36}$ This strategy proved successful. By mid-1903 Moore had prevailed, and the 'victory over the National Board' was lauded by Patrick Pearse, editor of An Claidheamh Soluis. ${ }^{37}$

Moore was a keen participant in the various local and national battles waged by the League and regularly contributed forthright letters to the press. Of vital concern to Hyde at the end of 1903 was the disappointing progress in the teaching of Irish in the national schools in the west: "The tide is rising everywhere except in the Irish-speaking districts themselves', he observed unhappily. ${ }^{38}$ At this time Irish could be taught outside the regular curriculum with teachers receiving a small fee for forty one-hour lessons or eighty lessons of thirty minutes if pupils attended seventy-five per cent of the classes. In County Mayo it was 'entirely the fault' of the school managers, usually priests, Hyde believed, 'that Irish is not properly taught there. These managers don't believe in our movement, and hence they won't do anything' ${ }^{39}$ His solution was to bring pressure to bear on the bishops. While there was cooperation with the League

\footnotetext{
${ }^{33}$ Appendix to seventieth report of the Commissioners of National Education in Ireland for the year 1903 (1905) Cd. 2373, Appendix F, Rules and Regulation, 112; Moore to editor of the Freeman's Journal, 4 Feb. 1903 (NLI, Moore papers, MS $10,571 / 1)$.

${ }^{34}$ Moore to editor of the Freeman's Journal, 4 Feb. 1903 (NLI, Moore papers, MS $10,571 / 1)$.

${ }^{35}$ Hyde to Moore, 7 Feb. 1903 (NLI, Moore papers, MS 10,561/21); Douglas Hyde, Mise agus an connradh (go dti 1905) (Dublin, 1937), 114-15.

${ }^{36}$ Hyde to Moore, [Feb-Mar. 1903] (NLI, Moore papers, MS 10,561/21).

${ }^{37}$ Pearse to Moore, 10 July 1903 (ibid., MS 10,561/30).

${ }^{38}$ Hyde to Moore, 22 Oct. 1903 (ibid., MS 10,561/21).

${ }^{39}$ Ibid.
} 
in the dioceses of Killala and Achonry, where one clerical opponent underwent a Pauline conversion and was 'now wild for the language', Archbishop John Healy of Tuam remained lukewarm. ${ }^{40}$

School managers were not Hyde's sole worry. Until the spring of 1907 he trenchantly opposed the reductions in teachers' remuneration imposed by James Bryce, the chief secretary, by lobbying the government, Augustine Birrell (Bryce's successor), and the IPP; he also encouraged Moore to write to the press and members of the League to approach their MPs. ${ }^{41}$ Moore spoke on the subject at a large public meeting of the Gaelic League in Castlebar on New Year's Day 1907 and strongly condemned anti-Irish school inspectors in the Castlebar district who were indifferent, if not hostile, to bilingual schools. ${ }^{42}$ After local agitation and with Hyde's assistance, one Mayo inspector was removed and half a dozen rebuked by William Starkie, the supportive resident commissioner of education. ${ }^{43}$

From 1903 Hyde was keen to have Moore, his reliable ally and confidant, join the Coiste Gnótha of the Gaelic League - the rather unwieldy and increasingly fractious national executive committee which was composed of Dublin and country representatives. ${ }^{44}$ Moore enjoyed a growing profile as a language advocate at both a county and a national level. In County Mayo he helped organize the annual feis and offered a substantial prize for a two-act play in Irish at the 1907 gathering. ${ }^{45}$ However, though nominated as a provincial representative in 1904, 1906 and 1907, he was not elected to the Coiste Gnótha until August 1908. He served on the education and organization sub-committees until his resignation in May 1911 when he moved his family to Belgium. ${ }^{46}$ His service coincided with the heated campaign to have Irish accepted as a matriculation subject for the new National University of Ireland. This was the League's greatest triumph and one in which Moore played a notable role. It is necessary first to provide a brief outline of the background.

At a student gathering in November 1908 Father William Delany, president of University College Dublin (UCD) and a member of the new university senate, let it be known that he did not approve of making Irish an obligatory requirement for matriculation. Though

\footnotetext{
${ }^{40}$ Hyde to Moore, 27 Dec. 1904 (NLI, Moore papers, MS 10,561/21).

${ }^{41}$ Dunleavy and Dunleavy, Douglas Hyde, 298-9.

${ }^{42}$ Micheál Ó Cléirigh to Moore, 24 Dec. 1906 and 5 Jan. 1907 (NLI, Moore papers, MS 10,561/24); Freeman's Journal, 2 Jan. 1907.

${ }^{43}$ Hyde to Moore, 26 May 1907 (NLI, Moore papers, MS 10,561/21).

${ }^{44}$ Hyde to Moore, 3 Mar. 1903, ibid.

${ }^{45}$ An Claidheamh Soluis, 3 Nov., 1 Dec. 1906.

${ }^{46}$ Ibid., 30 July 1904, 4 Aug. 1906, 3 Aug. 1907, 5 Sept. 1908; Attendance of members at meetings of the executive and other committees of the Gaelic League, 1905-1920 (NLI, Connradh na Gaeilge, MS 5,179).
} 
he was speaking in a personal capacity, the Gaelic League regarded Delany's views as representative of the senate and in response called a mass meeting in the Rotunda to defend 'essential Irish'. This set the organisation on a collision course with the Catholic hierarchy. The bishops were not hostile to the language but, conscious that only about half of the secondary school population was taking Irish as an examination subject, they were opposed to restrictive admission requirements for fear that they might oblige some Catholic students to attend Protestant Trinity College. ${ }^{47}$ In mid-January 1909 the standing committee of the hierarchy issued a statement acknowledging that the question was one for 'fair argument', but made very clear its opposition to compulsion. ${ }^{48}$

For Moore the issue was a vital national principle with more farreaching implications for future generations than even home rule or the land question. ${ }^{49}$ His contributions were characteristically spirited whether at public demonstrations, as in Castlebar in mid-January and Ballyhaunis on St Patrick's Day 1909, or in letters to the provincial and national press. ${ }^{50}$ Moore was especially critical of the declaration of the standing committee, believing it had 'stirred the enthusiasm of the people for the Irish language more than all the efforts of the Gaelic League for the last ten years'. ${ }^{51}$ The hierarchy favoured Irish as an optional rather than a required subject, but for the Gaelic League 'optional status was marginal status'. ${ }^{52}$ Not wishing to add to the controversy, An Claidheamh Soluis simply expressed regret at the bishops' position. ${ }^{53}$ Moore, by contrast, published a strident letter, in all the national dailies and in the Connaught Telegraph, in which he made clear his belief that as a body the bishops had deliberately set themselves to cross the popular path:

In my opinion nothing could be more disastrous for the Church than to be identified with such an anti-Irish policy; it will inspire suspicion and distrust, such as has been the ruin of the Church of France; it will induce many to doubt if the Bishops are fit and suitable people to guide the educational destinies of the Universities. ${ }^{54}$

\footnotetext{
${ }^{47}$ Dunlevy and Dunlevy, Douglas Hyde, 211.

${ }^{48}$ McMahon, Grand opportunity, 76; David W. Miller, Church, state and nation in Ireland, 1898-1921 (Dublin, 1973), 234-6.

${ }^{49}$ Moore to editor of the Freeman's Journal, 1 Jan. 1909 (published 4 Jan. 1909).

${ }^{50}$ Connaught Telegraph, 23 Jan. 1909; Tuam Herald, 20 Mar. 1909.

${ }^{51}$ Statement by Moore, [1909] (NLI, Moore papers, MS 10,567).

${ }^{52}$ Dunleavy and Dunleavy, Douglas Hyde, 305.

${ }^{53}$ McMahon, Grand opportunity, 77.

${ }^{54}$ Moore to editor of the Freeman's Journal, 22 Jan. 1909 (published on 25 Jan. 1909); Irish Times, 25 Jan. 1909; an abbreviated version appeared in the Irish
} 
Though commended by members of the Gaelic League in County Mayo, such sentiments left Moore open to the charge of anticlericalism. This was made still more likely by his brother's virulent and public anti-Catholicism (see section 3 below). ${ }^{55}$

Moore's intervention brought him into sharp conflict with Archbishop Healy, who, though initially a supporter of the Gaelic League, was bitterly opposed to the matriculation campaign and the confrontational tactics of the League. He treated 'advocacy of this view within his archdiocese as direct defiance of the bishop's authority'. ${ }^{56}$ This was not a matter of little consequence as the archbishop was one of the five Catholic clerics appointed to the senate of the new university ${ }^{57}$ Healy was also a member of the committee of the Connacht Irish College - one of a number of voluntary provincial colleges established by the Gaelic League to remedy the lack of competent Irish language teachers. In 1904 he offered a house in Tourmakeady rent-free and facilitated the establishment of the College. ${ }^{58}$ The training colleges were financed partly by the executive of the Gaelic League and partly by local subscription. The constitution of the Connacht College did not grant a right of veto or control to any individual member, however eminent, but Archbishop Healy appeared to claim such a privilege on denominational grounds following the death of Micheál Breathnach, the first principal, in October 1908. This went against the fundamental democratic and non-sectarian principles of the Gaelic League. The dispute over the control of staffing at the College was exacerbated by the archbishop's stance on the matriculation issue.

Healy attempted to close down debate on the issue of compulsory Irish in a typically autocratic fashion by maintaining that it was a matter of conscience to oppose compulsory Irish lest it force Catholic students to attend Trinity College and that it was no longer a matter for argument following the statement by the episcopal standing committee ${ }^{59}$ When challenged by Moore at a committee meeting of the Connacht College on 25 February that 'the people of

Independent, 25 Jan. 1909; Connaught Telegraph, 30 Jan. 1909. Similar sentiments were expressed in a letter dated 1 Jan. 1909 published in Connaught Telegraph, 9 Jan. 1909.

${ }^{55}$ For an example of praise see Conor Maguire (Claremorris Gaelic League) to Moore, 5 Jan. 1909 (NLI, Moore papers, MS 10,561/23).

${ }^{56}$ Patrick Maume, 'Healy, John', in DIB [http://dib.cambridge.org/viewReadPage. do?articleId=a3895, accessed 25 Mar. 2014].

${ }^{57}$ Miller, Church, state and nation, 197.

${ }^{58}$ Tuam Herald, 10 Mar. 1906.

${ }^{59}$ An Claidheamh Soluis, 6 Mar. 1909; W.P. Ryan, The pope's green island (London, 1912), 174. 
Ireland have spoken with no uncertain voice in favour of Irish, and their opinions should be respected,' the archbishop responded that he did not 'give a pinch of snuff for their opinions' ${ }^{60}$ This ill-judged remark caused a furore as it was out of step with public opinion as well as the position of the IPP and the county councils. In the view of one contemporary, Healy assumed 'a curious position, not easy to explain, between popularity and unpopularity'. ${ }^{61}$ The outburst may have been motivated by his displeasure that a public meeting in favour of the demand had been held in Tuam the previous month, following which the clergy were effectively muzzled by 'episcopal padlock'. ${ }^{62}$ The archbishop's comment was criticized by Pearse in $A n$ Claidheamh Soluis. ${ }^{63}$ Moore also took the prelate to task and argued that the question of compulsory Irish was not a matter of conscience but rather of expediency. He instanced the stances of other members of the hierarchy such as Cardinal Michael Logue, who stated that "Catholics are "as free as the wind" to adopt any opinions they think right'. Moore queried pointedly whether Archbishop Healy was

the only person in the diocese who is allowed to have a conscience? Are all our consciences to lie in his pocket to be disposed of even in temporal matters as he thinks best? This would be all very well if he were infallible but even the Pope does not claim this sort of infallibility. ${ }^{64}$

Though he supported Moore, Hyde did not wish to intrude on a local controversy but as president of the League he was inexorably drawn into it. He sought to keep the university and staffing questions separate. This approach allied to Hyde's diplomacy helped placate Healy and save the situation. After some delicate manoeuvring, a compromise was reached in April 1909 which allowed the committee to retain the power to appoint teachers and set courses of study but permitted the archbishop 'a veto on any teacher who was immoral or an enemy of religion in the broad sense of the word'. ${ }^{65}$ There was also general agreement regarding the new principal, Pádraig Ó Domhnalláin. Thereafter, Healy, whose health was in decline, refrained from further eruptions on the matriculation issue.

In early May Moore, apparently on his own initiative though

${ }^{60}$ An Claidheamh Soluis, 6 Mar. 1909; Irish Independent, 12 Mar. 1909.

${ }^{61}$ Ryan, The pope's green island, 172.

${ }^{62}$ Unpublished letter by Moore, [c. Mar. 1909] (NLI, Moore papers, MS 10,567).

${ }^{63}$ McMahon, Grand opportunity, 79.

${ }^{64}$ Unpublished letter by Moore, [c. Mar. 1909] (NLI, Moore papers, MS 10,567).

${ }^{65}$ Hyde to Moore, 7 Apr. 1909 (NLI, Moore papers, MS 10,561/21); Ryan, The pope's green island, 175 . 
almost certainly with Hyde's knowledge, sought to arrive at an understanding with the hierarchy on the compulsion question. ${ }^{66}$ He invited Canon Arthur Ryan, parish priest of Tipperary, a strong proponent of compulsory Irish, and an old classmate in St Mary's College Oscott, to act as mediator. Moore stated that members of the Gaelic League were not 'violent extremists' but were willing 'to smooth the way for a reconciliation'. He proposed a transition period of three years during which Irish would not be compulsory but would be 'a well-marked voluntary subject'. After this Irish would become compulsory, and the inclusion of an Irish examination could be facilitated by jettisoning the Early English components of the English matriculation examination: 'simple questions relating to Irish instead of Anglo-Saxon will not frighten anyone away', he reasoned. Moore pointed out that the League would not countenance the postponement of the question beyond the five-year term of the first university senate or accept endowment of professorships or scholarships as a substitute for 'compulsory matriculation' ${ }^{67}$ Ryan brought Moore's suggestion to the attention of his archbishop, Thomas Fennelly, who responded by enquiring if Moore had the authority to make such proposals. ${ }^{68} \mathrm{In}$ fact no one had been authorized by the Gaelic League to make terms. But Moore had taken soundings from several influential members of the League. These included Father Michael O'Hickey, for whom the proposed settlement was 'entirely satisfactory', and Eoin MacNeill, who believed that the colonel had 'proceeded very wisely'. ${ }^{69}$ Moore reported to Ryan that while the Gaelic League wanted Irish obligatory for matriculation without delay, it would agree to three years as a compromise:

All agree that if this is agreed to in a straight forward way the G[aelic] League will be practically unanimous in accepting the settlement as a definite solution of the problem and that everything will be done to make the road smooth and easy. We will do all we can to get the County Councils to levy a rate for the University etc. etc. ${ }^{70}$

\footnotetext{
${ }^{66}$ Moore discussed with Hyde the optional use of Irish for an initial period: see Moore to Hyde, 24 May [1909] (NLI, Hyde papers, MS 21,098/1).

${ }^{67}$ Moore to Ryan, [Apr-May 1909] (NLI, Moore papers, MS 10,567).

${ }^{68}$ Ryan to Moore, 5 May 1909 (NLI, Moore papers, MS 10,567).

${ }^{69}$ O'Hickey to Moore, 8 May 1909; Mac Neill to Moore, 14 May 1909 (NLI, Moore papers, MS 10,567).

${ }^{70}$ Moore to Ryan, 17 May 1909 (NLI, Moore papers, MS 10,567).
} 
Ryan placed the matter in the hands of Archbishop William J. Walsh of Dublin but nothing came of it. Moore's sensible scheme was eclipsed by the outcry that followed the removal of Father O'Hickey from the chair of Irish at Maynooth for refusing to apologize for intemperate attacks on all opponents of compulsion including the clerical members of the university senate, Daniel Mannix, president of Maynooth, among them. ${ }^{71}$ The ensuing uproar may have reinvigorated the Gaelic League's campaign but it postponed a resolution of the matriculation question. The position of the county councils was critical. Many declared that unless Irish was made compulsory they would make it a condition that those who held county council scholarships should enjoy them at Trinity. ${ }^{72}$ Eventually in June 1910 it was agreed by the senate that Irish would be compulsory for matriculation from 1913 onwards.

For Moore the Irish language was a unifying and conciliatory force among people of all political and religious faiths. He believed that participation in the Irish Volunteers, which will be discussed in sections IV and V, served the same purpose. He told a Tipperary audience that the Gaelic League and Volunteers were often synonymous: 'where I find one I am sure to find the other. The spirit which animates them ought to be the same: a spirit of friendliness towards all Irishmen and broad toleration for their opinions. ${ }^{973}$ As a volunteer organizer he recalled that the first to step forward to assist were members of the Gaelic League. They "carried the torches showing the way to the timid and the hesitating; they did the practical work of the Volunteers' ${ }^{74}$ Though never again prominent in the Gaelic League, Moore retained a life-long interest in the fortunes of the Irish language. As a senator in the 1920s, he claimed that 'if any act is found to contain a clause protecting or advancing the Irish language, it will generally be found to have originated in the Senate'. ${ }^{75}$

\section{Fraternal strife, 1902-33}

The breakdown of relations with his erratic and querulous brother George was a source of sadness and regret to Moore. Their letters

\footnotetext{
${ }^{71}$ Patrick Maume, 'O‘Hickey, Michael (Ó Hiceadha, Micheál)', in DIB [http:// dib.cambridge.org/viewReadPage.do?articleId $=\mathrm{a} 6808$, accessed 25 Mar. 2014); Dunleavy and Dunleavy, Douglas Hyde, 306; Miller, Church, state and nation, 23941.

${ }^{72}$ Diarmid Coffey, Douglas Hyde: president of Ireland (Dublin, 1938), 102.

${ }^{73}$ Draft of a speech by Moore, n.d. (NLI, Moore papers, MS 10,571/2).

${ }^{74}$ Moore to editor of An Claidheamh Soluis, 16 Nov. 1914 (published 21 Nov. 1914).

${ }^{75}$ Moore to editor of The Nation, 7 Feb. 1928 (NLI, Moore papers, MS 10,571/7).
} 
revealed a warm rapport during Moore's military service in India and South Africa. In 1892 George offered Moore Hall as a residence to his brother, 'so long as the place is mine it is yours in every respect'. ${ }^{76}$ Two years later the novelist dedicated his novel, Esther Waters, to Maurice, who responded by asking George to be his son's godfather. ${ }^{77}$ But from 1903 the fondest of brothers grew estranged over religion and land. Maurice and his family continued to live in Moore Hall but the house and estate of some 12,500 acres had been settled on George as the eldest son following the death of their father in 1870 and, failing children by George, on Maurice as second son. The furniture and other assets were left to their mother, Mary. ${ }^{78}$ When George removed to Paris and later London and then to Dublin, Maurice oversaw the management of the estate by the agent Tom Ruttledge. Following Mary Moore's death in May 1895, her will named George and Maurice as equal residuary legatees but George disentailed the house and all property and became the sole owner. This did not engender any immediate rancour. However, following his return from South Africa, Maurice was distressed to find that his brother had publicly and vehemently renounced Catholicism, claimed it was incompatible with literature, sought formal admission to the Church of Ireland, and denied that his family was ever genuinely Catholic. $^{79}$

The rift deepened in 1905 when George proposed to sell the land but not the house under the Wyndham Land Act (1903). This measure encouraged landlords to sell by offering payment in cash and a bonus on the sale price for entire estates. Although no businessman, the novelist presciently recognized that if landlords did not accept these terms, "within the next ten years they will lose half their properties' ${ }^{80}$ However, Maurice had other ideas. His interest in rural development was informed by romantic notions of improving nationalist landlords in which category he placed his father and himself. To his brother's growing annoyance he floated various schemes, such as building a saw mill, and was unenthusiastic about any sale. Some land parcels and timber were disposed of in 1906 and 1908. George became increasingly concerned about expenditure on

\footnotetext{
${ }^{76}$ George Moore to Maurice Moore, 28 June 1892 cited in Hone, George Moore, 181.

${ }^{77}$ Hone, George Moore, 193-4.

${ }^{78}$ Preface by Maurice Moore to a bound set of letters with his brother documenting their quarrel, 8 Apr. 1937 (NLI, Maurice and George Moore papers, MS 4,894).

${ }^{79}$ Hone, George Moore, 249-51; Dunleavy, George Moore, 128; Frazier, George Moore, 331-3.

${ }^{80}$ Maurice Moore to George Moore, 5 April 1905 cited in Hone, George Moore, 263.
} 
Moore Hall to which a number of improvements were made during his brother's residency. Claiming to have spent $£ 1,000$ on the estate, George expressed serious alarm at the outflow in July 1909 and feared that 'the property won't last out even my lifetime' ${ }^{81}$ Periods of silence between the brothers subsequently became more common. Occasional visits by Maurice to George in Dublin to discuss estate accounts usually ended in theological quarrels.

In 1910-11 the mounting dissension between the brothers over the estate and religion converged as negotiations, initiated by Ruttledge, with the Congested Districts Board paved the way for the sale of the property, which eventually realized $£ 30,000$ net; the house and five hundred acres around it were retained. ${ }^{82}$ This also drew attention to the education of Maurice's children in Catholic schools in England and to the fact that their fees were paid from the estate account. When reminded of this George perversely threatened to withdraw the financial assistance provided unless his nephews were raised as Protestants. Only in this way could the children qualify as his heirs. Maurice's offer to repay the money was refused. This was not the first time that George had imposed conditions on his financial benevolence. In 1901, before he cast aside his fleeting interest in the revival of the Irish language, he had threatened to disinherit his nephews unless they spoke Irish fluently; as a result an Irishspeaking nurse was employed at the novelist's expense, but with little success. ${ }^{83}$ Maurice's son Ulick was also for a time a pupil at Pearse's Scoil Éanna in Dublin. In December 1910 Augustus Moore, a younger brother, journalist and playwright, died in London after an operation. In an obituary notice the Irish Times stated that he came from 'an old Irish and Roman Catholic family' ${ }^{84}$ George immediately wrote a letter to the editor objecting to 'this libel' on his ancestors' religious beliefs. 'There are not centuries of Catholicism behind me but one single generation,' his letter closed, 'and I hope that the next generation will be Protestant. I shall have no hesitation in leaving any money I may have on the condition that my heir shall carry on the Protestant traditions of the family. ${ }^{, 85}$ Increasingly ill at ease at being financially beholden, Maurice concluded that his brother's attitude to the children's religious upbringing was 'too improper to

\footnotetext{
${ }^{81}$ George Moore to Maurice Moore, 6 July 1909 in Helmut E. Gerber (ed.), George Moore on Parnassus: letters (1900-1933) to secretaries, publishers, printers, agents, literati, friends, and acquaintances (Newark, 1988), 166.

${ }^{82}$ Hone, George Moore, 304.

${ }^{83}$ Preface by Maurice Moore (NLI, Maurice and George Moore papers, MS 4,894); Hone, George Moore, 229-31.

${ }^{84}$ Irish Times, 29 Dec. 1910.

${ }^{85}$ Ibid., 30 Dec. 1910.
} 
be passed over'. ${ }^{86}$ In May 1911 he moved to Brussels and, having sought Pearse's advice on schools, enrolled 15-year-old Ulick at the Jesuit College in that city. ${ }^{87}$ Moore Hall was closed, never to be reopened, and thereafter the brothers met only occasionally in London or Brussels.

The deteriorating relationship between the siblings was exacerbated by Maurice's unhappiness at George's literary endeavours. He was outraged at the portrait of himself in Salve, the second volume of George's trilogy, Hail and Farewell. This occasioned a particularly bitter exchange of letters in October 1912 in which Maurice protested that he had been depicted as 'mentally contemptible and physically ridiculous'. ${ }^{88}$ As Elizabeth Grubgeld has put it, George Moore's letters illustrate 'the apparently senseless demise of a close brotherly affection through Moore's incessant insulting obsession with the imagined offenses of his brother's religion' ${ }^{89}$ Maurice recalled that the incident 'left a wound that never completely healed'. ${ }^{90}$ George sought to ease the situation by helping Maurice with his biography of their father, An Irish Gentleman: George Henry Moore. When Werner Laurie, the publisher, suggested that a preface by the novelist would 'make an enormous difference to the reception of the book' George duly consented. ${ }^{91}$ However, instead of providing a focus around which the two men could rally Maurice found unacceptable his brother's insinuation that their father committed suicide and died without the sacraments. There was further pointless riling when George ridiculed the frontispiece of his brother in uniform as a 'terrifying portrait of you - you in all your youth and beauty, the darling of the garrison hacks. So now we know the light in which you wish people to see you!' ${ }^{92}$ Before the book went to press in July 1913, and having consulted relatives, Maurice inserted an erratum slip: 'What the prefacer writes regarding the mode of his father's death must be taken as expressing his wishes, and not the facts. ${ }^{93}$ George angrily accused Maurice of provoking controversy to boost

\footnotetext{
${ }^{86}$ Preface by Maurice Moore (NLI, Maurice and George Moore papers, MS 4,894).

${ }^{87}$ Séamas Ó Buachalla (ed.), The letters of P. H. Pearse (Gerrards Cross, 1980), 245

${ }^{88}$ Maurice Moore to George Moore, 27 Oct. 1912 (NLI, Maurice and George Moore papers, MS 4,894); Frazier, George Moore, 384; Gray, A peculiar man, 279-80.

${ }^{89}$ Elizabeth Grubgeld, George Moore and the autogenous self: the autobiography and fiction (New York, 1994), 45.

${ }^{90}$ Preface by Maurice Moore (NLI, Maurice and George Moore papers, MS 4,894).

${ }^{91}$ T. Werner Laurie to George Moore, 3 Feb. 1913, ibid.

${ }^{92}$ George Moore to Maurice Moore, 24 Apr. 1913 in Gerber (ed.), George Moore on Parnassus, 263.

${ }^{93}$ Maurice Moore, An Irish gentleman: George Henry Moore (London, 1913).
} 
sales. ${ }^{94}$ The colonel's reply was devastating:

The kindly good-natured George that I knew for fifty years is dead; for that George I still feel the same affection, the same gratitude for many kind actions. But for the altogether different person who has grown out of him since about the period of Augustus's death or a little before \& who has inflicted on me so many unkind and unbrotherly blows my feelings could not be the same. Prosperity \& exaltation alter certain characters, \& so I suppose it must be. ${ }^{95}$

The breach was now irrevocable.

\section{The Irish Volunteers, 1913-14}

Moore's energies were soon absorbed by an irresistible new project - the Irish Volunteers. The intertwined convictions that home rule was imminent and that Ulster opposition was a bluff explain the slow nationalist response to the formation of the Ulster Volunteer Force (UVF) in January 1913. It was not possible to indulge such delusions by November. Indeed there was growing unease in nationalist circles by this point at reports from Westminster, which suggested that Redmond might yield to pressure to agree to partition and the attenuation of home rule. The Irish Volunteers were established principally to ensure its unconditional implementation. Like many nationalists, Moore broadly supported the efforts of the IPP but was critical of the restrictive financial aspects of the home rule measure. In his submission to the Royal Commission on the Rebellion, he recalled being 'scoffed at by my London Unionist friends, who prophesised that I could not raise a hundred men in Ireland to defend Home Rule'. ${ }^{96}$ Undeterred, he returned to Mayo in December 1913 to promote the Volunteers. In Castlebar, Moore initially had to 'propitiate' a number of factions at odds with one another and 'square ecclesiastical authority in the town'. ${ }^{97} \mathrm{He}$ later addressed public meetings in Westport and Ballina and publicized the Volunteers in the local press. One correspondent described his efforts as 'an inspiration to the people of this district at the proper

\footnotetext{
${ }^{94}$ George Moore to Werner Laurie, 17 July 1913 (NLI, Maurice and George Moore papers, MS 4,894).

${ }_{95}^{5}$ Maurice Moore to George Moore, 18 July 1913, ibid.

${ }^{96}$ Draft of Moore's statement to the Rebellion Committee, [1916] (NLI, Moore papers, MS 10,572).

${ }^{97}$ Moore to Casement, 4 Jan. 1914 (NLI, Roger Casement papers, MS 13,080/2i).
} 
moment' ${ }^{98}$ By the end of January he was 'prominently identified' with the Volunteers in Mayo by the police. ${ }^{99}$

It was about this time also that Moore joined the provisional committee of the Volunteers in Dublin. Of his first meeting, he recalled

about twenty-five members present; nearly all of them were young men, some merely boys of twenty. None of them knew anything of military affairs or the division of battle more than a spinster, but they had hired halls for drilling and obtained the free services of excellent sergeants to instruct them. Except for Mr John MacNeill and Mr Pearse and Mr MacDonagh, I had never seen or heard of any of them before. ${ }^{100}$

Addressing the political allegiance of those present, Moore maintained that they included 'about two extremists and four or five young boys under their domination', five or six Sinn Féiners, broadly defined, who distrusted the IPP but 'were not revolutionists', and 'idealists', many known to Moore through the Gaelic League, such as MacNeill, Pearse, MacDonagh, Plunkett and O'Rahilly. ${ }^{101}$ The remainder, including Moore himself, were moderate but not uncritical followers of the IPP. MacNeill concurred; he claimed that the provisional committee was 'widely representative' by design. ${ }^{102}$ This contrasts with Bulmer Hobson's later account of the Irish Volunteers, which paints an uncomplicated picture of IRB control from the outset with MacNeill as a mere figurehead. ${ }^{103}$ In fact, the IRB was far more prominent after the split in the movement in September 1914. Before this MacNeill, Moore and Roger Casement worked closely together and played a pivotal role.

As the only member of the provisional committee with military expertise, Moore was the obvious choice for the position of inspectorgeneral. Moore believed that the force needed to be under the strictest military discipline because 'the greatest danger that can exist in a state is a body of half disciplined men, serving under irresponsible leaders' ${ }^{104}$ In addition, in February 1914 the provisional committee

\footnotetext{
${ }^{98}$ Martin Nally (Mayo Abbey, Ballyglass, Co. Mayo) to Moore, 11 Jan. 1914 (NLI, Moore papers, MS 10,561/24).

${ }^{99}$ RIC Inspector-General's monthly report for January 1914 (TNA, CO 904/92).

${ }^{100}$ Draft of Moore's statement to the Rebellion Committee, [1916] (NLI, Moore papers, MS 10,572).

${ }^{101}$ Ibid.

${ }^{102}$ MacNeill to Casement, 25 Nov. 1913 (NLI, Casement papers, MS 36,203/2).

${ }^{103}$ Witness statement of Bulmer Hobson (BMH, WS 51, 3-10).

${ }^{104}$ Moore to Casement, 6 Dec. 1913 (NLI, Casement papers, MS 13,0802i).
} 
established a number of sub-committees in which Moore took an active part. As well as his work on the uniform and equipment subcommittee, he served on both the country and the Dublin city and county sub-committees, which were charged with establishing new Volunteer corps. In June 1914 he became a member of the newly created military inspection sub-committee.

Moore set out his conception of the Volunteers in the first issue of the Irish Volunteer newspaper in February 1914: 'to defend the soil of Ireland from foreign invasion and to maintain the rights and liberties common to all Irishmen.' ${ }^{105}$ This drew deliberately on the example of the Volunteer corps established in the late 1770s to which frequent reference was made in 1913-14. But it also underscored the desire for rapprochement with northern unionists. In a telling letter to Casement, Moore was adamant that

No section in Ireland must be allowed to obtain control for its own purpose and we must extend the hand of brotherhood not only to those who have been Nationalists in the past but to those who have been Unionists, not only to the men of the southern provinces but to the Northern Protestants. ${ }^{106}$

This reconciliatory impulse was echoed in the manifesto of the Volunteers which proclaimed that it was 'open to all able-bodied Irishmen without distinction of creed, politics or social grade'. ${ }^{107}$ For Moore this also echoed the principles of the Gaelic League.

Defending Ireland required military efficiency. Scarcities of arms, funds and officers were major obstacles to achieving such martial proficiency. The Irish Volunteers were rich in aspiration but poor in means. Casement captured the scale of the challenge in December 1913: 'There is no doubt of the extreme desire of the youth of Galway to enrol - to "enlist" in an Irish Army - but there is no equipment and no organisation here, or any human fibre (that I can see) with which to weave it. ${ }^{108}$

Moore became increasingly perturbed in the early months of 1914 by the growing belligerency of the UVF and the indecisiveness of the government's response. This dangerous situation and the manifestly inferior military position of the Irish Volunteers could be remedied,

\footnotetext{
${ }^{105}$ Maurice Moore, 'Shoulder arms and defend your country', Irish Volunteer 1:1 (7 Feb. 1914), 6.

${ }^{106}$ Moore to Casement, 6 Dec. 1913 (NLI, Casement papers, MS 13,0802i).

${ }^{107}$ Manifesto of the Irish Volunteers, 1913 (NLI, Bulmer Hobson papers, MS $13,174 / 2)$.

${ }^{108}$ Casement to Moore, 11 Dec. 1913 (NLI, Moore papers, MS 10,561/3).
} 
he believed, if the Territorial Act of 1914 was extended to Ireland, since both nationalists and unionists could enlist in an Irish territorial force. Moore held that there was 'everything to gain and nothing to lose'. Such a practical scheme would have a positive impact on English public opinion, 'combat the demand for conscription by the Tories', allow English territorials to 'be kept for the defence of England' as Ireland would be able to defend herself, and boost the chances of a Liberal victory at the next election. ${ }^{109} \mathrm{At}$ different times Moore and MacNeill appear to have raised the territorial idea with members of the provisional committee. 'All seem quite satisfied', MacNeill reported, 'or at all events by no means averse. ${ }^{110}$ Similarly, Moore wrote: 'in no case has the proposal been disapproved even in the case of the most extreme men; even separatists have approved. ${ }^{\prime 11}$ This is not surprising. There was a unanimous desire to see the Volunteer movement perfect its discipline and take firm root throughout the country. To this end it was paramount that the authorities did not perceive the Volunteers as 'revolutionary in the most dangerous sense'. ${ }^{112}$ With this view in mind, Moore sought to win over the government. He informed the Rebellion Committee that for about four months he had engaged in discussions with John Edward Seely, secretary of state for war, about an Irish territorial force but without result. When the Curragh incident cost the minister his portfolio at the end of March 1914, Moore concluded that the idea was dead. He advised Redmond that the incident "will have so weakened the Ministry that they will be too timid to carry out our territorial policy'. ${ }^{113}$ So it proved. Nonetheless, Moore maintained his interest in an Irish territorial force. Both he and Casement, even more so, clung to the idea of winning over Ulstermen through the Volunteer movement. The latter later reminded Moore of the correct title of the organization: 'IRISH Volunteers, not NATIONAL or NATIONALIST Volunteers (the latter wholly damnable)'. ${ }^{114}$ They even developed their own scheme for the co-operation of the Irish and Ulster Volunteers to defend Ireland in the event of European war. The territorial idea was reactivated, albeit under different circumstances, when Britain entered the First World War.

\footnotetext{
${ }^{109}$ Untitled memo by Moore regarding the Territorials, [c. Mar.-April 1914] (ibid., MS 10,582).

${ }^{110}$ MacNeill to Moore, 27 Mar. 1914 (ibid., MS 10,561/27).

${ }^{111}$ As note 109 .

${ }^{112}$ MacNeill to Moore, 2 May 1914 (ibid., MS 10,561/27).

${ }^{113}$ Moore to Redmond, 31 Mar. 1914 (ibid., MS 10,561/34).

${ }^{114}$ Casement to Moore, 2 June 1914 (ibid., MS 10,561/3).
} 
The leadership of the IPP did not welcome the establishment of a nationalist militia at such a delicate political juncture but did not openly condemn it. While some MPs tried to discourage the Volunteers, such as Richard Hazelton in Galway in December 1913, many local companies were formed by members of the Party's affiliate organizations - the United Irish League and the Ancient Order of Hibernians (AOH), particularly in southern and western counties. ${ }^{115}$ The Volunteers made steady but not spectacular progress. By February 1914 the RIC inspector-general reported that companies had been established in seventeen counties. ${ }^{116}$ Enrolment subsequently surged as the political situation deteriorated following the Curragh incident, UVF gun-running, and the reluctant acceptance by the IPP of some form of separate treatment for Ulster.

The constitution of the Volunteers prohibited affiliation to a political party but the need for a modus vivendi with the IPP grew stronger as 1914 progressed and Volunteer numbers increased. Without the prior approval of the provisional committee, MacNeill, Casement and Moore approached the Irish Party leadership in spring 1914 to seek an understanding and to offer renewed assurances that the Volunteers would not endanger the IPP's pursuit of home rule. Moore was chief intermediary and to this end he spent several weeks in London. MacNeill observed that by attending an interview with the party leadership in late March, Moore had 'done the country a great service':

It was necessary to remove all possibility of misinterpreting our aims, and as we have to work by ourselves we might easily be thought to contemplate creating fresh divisions, and some of the parliamentary leaders - not, I think, Redmond - seem rather prone to suspect what they do not actually control. To my mind, if any crisis arises, it could be a great disaster to have a war of Nationalist factions. ${ }^{117}$

Further meetings with the IPP ensued in both Dublin and London, with the result that by early April Redmond and Joseph Devlin, the powerful MP for West Belfast and national president of the $\mathrm{AOH}$, had both privately approved the Volunteers. This development was not without danger. In an astute letter to Moore, Casement cautioned against any overt alliance:

\footnotetext{
${ }^{115}$ RIC Inspector-General's monthly report for Dec. 1913 (TNA, CO 904/91).

${ }^{116}$ RIC Inspector-General's monthly report for Feb. 1914 (TNA, CO 904/92).

${ }^{117}$ MacNeill to Moore, 27 Mar. 1914 (NLI, Moore papers, MS 10,561/27).
} 
We are seeking to beget the idea of a national service quite apart from politics - to uphold and maintain the rights and liberties common to all Irishmen. How then could we ally with one political body? ... if we depart from the non-political standpoint clearly announced at the start we shall wreck the Volunteers, and split a healthy national movement into a welter of factions. ${ }^{118}$

Moore was privy to but not directly involved in the negotiations with the IPP in May as he spent much of that month organizing or inspecting Volunteers in counties Derry, Donegal, Fermanagh and Tyrone. He generally refrained from political comment but the fear of partition among northern nationalists prompted him to warn Birrell that 'if an attempt is made to cut off National[ist] counties such as Tyrone and Fermanagh or a city like Derry from National[ist] Ireland, very serious trouble will ensue ... a 'clean cut' ... will not produce peace'. ${ }^{119}$ Moore was, and remained, opposed to any form of partition.

Until early June 1914 it appeared that the discussions between MacNeill and the IPP would lead to an amicable settlement. At issue was the composition of a six-member executive committee or governing council which, under a new constitution, would replace the original provisional committee. The somewhat politically naïve MacNeill was keen to ensure that the Volunteers did not become 'an annex to the $\mathrm{AOH}$ ' and that the membership of the governing council would prove 'worthy of confidence from the Volunteer standpoint'. ${ }^{120}$ For this reason he proposed Willie Redmond as someone who would have the confidence of IPP and Volunteers alike. Keen to safeguard his political influence, John Redmond would not sanction this unless the new body was increased to eight by the addition of two men possessing his confidence. Furthermore, he warned MacNeill that he contemplated the establishment of 'a second body of Irish Volunteers and that 'it will be necessary for us [IPP] to take action without much further delay either in conjunction with you or otherwise'. ${ }^{121}$ Redmond's demand that the IPP should have greater representation on the governing body of the Volunteers 'to guarantee that the policy and administration of the movement were in complete accordance with the will of the people' was given impetus by J.P. Boland, MP for Kerry South, and Stephen Gwynn, MP for Galway, both members of

\footnotetext{
${ }^{118}$ Casement to Moore, 22 Apr. 1914 (ibid., MS 10,561/3).

${ }^{119}$ Moore to Birrell, 15 May 1914 (ibid., MS 10,561/2).

${ }^{120}$ MacNeill to Casement, 8 Apr. 1914 (NLI, Casement papers, MS 36,203/2).

${ }^{121}$ Redmond to MacNeill, 16 May 1914 (NLI, MacNeill papers, MS 10,883).
} 
the Gaelic League. ${ }^{122}$ Tellingly, Redmond's uncompromising stance coincided with the third reading of the home rule bill on 25 May. His additional nominees were Joseph Devlin and Dr Michael Davitt, son of the founder of the land league. ${ }^{123}$ Moore's name was suggested by MacNeill to bring the number to nine. ${ }^{124}$ Davitt, who had been notably cool on the Volunteers at the Rotunda meeting, was wholly unacceptable to MacNeill. He was 'bound in honour' to ensure that those in a position of control over the Volunteers were 'unreservedly in favour of the public aims and programme of the Volunteer movement'. ${ }^{225}$ This led to accusations of breach of trust on both sides. 'I understand from this', Redmond wrote to MacNeill on 3 June, 'that you no longer desire my cooperation or that of my friends in control of the movement, and I must now act accordingly. ${ }^{126}$ One week later he strong-armed the provisional committee to accept twenty-five of his nominees and the enlarged committee met for the first time on 14 July. Moore consented with reluctance to the Redmondite influx and later described it as 'a thoroughly bad arrangement which made a split inevitable'. ${ }^{127}$ But in the summer of 1914, as the Volunteers reached a high point, like so many others, Moore viewed the growing threat of war as an opportunity to secure home rule. Indeed at the end of July, he advised Redmond that 'If there is any hesitation on the part of the government in getting the King to sign the Home Rule Bill immediately the Irish reservists ought to be told not to join ... This is the only pressure we can exert against a combination of the two English parties'. ${ }^{128}$ Unlike Redmond, Moore had little faith in British promises.

The outbreak of war neutralized the seeming inevitability of conflict between nationalists and unionists. On 3 August Redmond committed himself to the war effort by offering the services of the Volunteers to defend Ireland. Moore at once recognized the implications. 'Your

\footnotetext{
${ }^{122}$ Redmond to MacNeill, 21 May 1914, Seaghán Ua Beoláin to MacNeill, 21 May 1914, Stephen Gwynn to MacNeill, 21 May 1914 (NLI, MacNeill papers, MS 10,883). See also James McConnel, The Irish Parliamentary Party and the third home rule crisis (Dublin, 2013), 286-8.

${ }^{123}$ Redmond to MacNeill, 26 May 1914 (NLI, MacNeill papers, MS 10,883).

${ }^{124}$ The nine were: MacNeill, Laurence Kettle, John Gore, The O'Rahilly, William Redmond, Roger Casement, Devlin, Davitt and Moore.

${ }^{125}$ MacNeill to Redmond, 29 May 1914 (NLI, MacNeill papers, MS 10,883).

${ }^{126}$ Redmond to MacNeill, 3 June 1914 (NLI, Redmond papers, MS 15,204). On this episode see Dermot Meleady, John Redmond: the national leader (Dublin, 2014), 274-6.

${ }^{127}$ Draft of Moore's statement to the Rebellion Committee, [1916] (NLI, Moore papers, MS 10,572); Bulmer Hobson, A short history of the Irish Volunteers (Dublin, 1918), 123.

${ }^{128}$ Moore to Redmond, 31 July 1914 (NLI, Redmond papers, MS 15,206/7).
} 
speech', he told Redmond, 'has quite transformed the situation and left Carsonites in gloom though I dare say they are glad enough to get out of their awkward fix. The mobilisation has however left us in a fix; it takes away in one swoop some 25,000 of our soldiers and most of our instructors just when they are most wanted. ${ }^{129}$ In Limerick the inspecting officer reported: 'We are growing into two or three battalions since Mr Redmond's offer to the Government. All classes and creeds have joined to defend Ireland.' ${ }^{130}$ The upsurge included many southern unionists, a point Moore later stressed in his written evidence to the Royal Commission on the Rebellion. ${ }^{131}$ This ostensible rapprochement was captured by James Johnston, private secretary to Lord Aberdeen, the lord lieutenant: 'I have not hitherto been in a position to identify myself actively with the movement but it seems to me that the moment has now arrived when all Irishmen should do anything in their power to assist their country.' ${ }^{132}$ Moore was inundated with offers of service. Robert A. Anderson, secretary of the Irish Agricultural Organisation Society, for example, aged fifty-three, able-bodied but without military experience, volunteered 'on the understanding given by Mr John Redmond ... that [the] $\mathrm{N}$ [ational] V[olunteers] are to be non-political and nonsectarian and are to concern themselves solely for the defence of this country against invasion and for the maintenance of law and order'. ${ }^{133}$ Another believed that his experience in the Indian Army equipped him to 'handle men of different races and religions'. ${ }^{134}$ Some sought a salary for which the inspector-general had simply no funds. But for many it appears that joining the Volunteers was a way to ease their conscience about not going to France on age or health grounds. For still others it was an opportunity for their firm to win a government contract. One Cork khaki manufacturer, with four sons in the army, sought a letter of introduction from Moore to General Lawrence W. Parsons, commander of the 16th (Irish) Division. ${ }^{135}$ In the second week of August the military headquarters staff of the Irish Volunteers moved to larger premises at 16 South Frederick Street, which was formerly used as the Nassau Hotel. ${ }^{136}$

\footnotetext{
${ }^{129}$ Moore to Redmond, 4 Aug. 1914, ibid.

${ }^{130}$ J.J. Holland to Moore, 8 Aug. 1914 (NLI, Moore papers, MS 10,561/19).

${ }^{131}$ Draft of Moore's statement to the Royal Commission on the Rebellion in Ireland, [1916] (NLI, Moore papers, MS 10,572).

${ }^{132}$ Johnston to Moore, 7 Aug. 1914 (ibid., MS 10,561/18).

${ }^{133}$ R. A. Anderson to Moore, 5 Aug. 1914 (ibid., MS 10, 561/1).

${ }^{134}$ Major H. Gordon Casserly to Dr Parkinson, 8 Aug. 1914 (ibid., MS 10,561/5).

${ }^{135}$ Paddy Cotter (Morrogh Bros \& Co. Ltd Woollen Manufacturers) to Moore, 16 Dec. 1914 (ibid., MS 10,561/6).

${ }^{136}$ Irish Times, 12 Aug. 1914.
} 
New offices notwithstanding, there were, as Moore put it in one letter, 'too many jobs on my unfortunate shoulders to give proper attention to any' ${ }^{137}$ The appointment of inspecting officers in each county was particularly pressing. Moore's office administration left much to be desired. His secretary, who eventually imposed order on the large volume of correspondence, later recalled that though 'a born leader of men', the colonel was 'completely indifferent to forms and regulations'. ${ }^{138}$ Despite the formidable obstacles that had to be negotiated, Moore believed that the Volunteers had by early September 1914 'succeeded in welding together all parties in at least three out of four southern provinces,' something achieved 'without money or patronage, but merely by the patriotism of our people, the moderation of our words and the wisdom of our actions'. ${ }^{339}$

Much now depended on how the War Office viewed the Volunteers and how the British cabinet handled home rule. MacNeill made clear to Redmond that the 'feeling here [in Dublin] is unanimous and strong against any unconditional arrangement which would favour the governmental status quo and fail to secure Home Rule'. ${ }^{140}$ Moore and Redmond envisaged the Volunteers being equipped and instructed for home defence without interference with its character. ${ }^{141}$ With the belief that some arrangement with the military was the only practicable way to acquire arms and training for the Volunteers, Moore met with General Sir Arthur Paget, who, until the end of August 1914, was general officer commanding in Ireland and whose earlier blundering was at the heart of the Curragh incident. A scheme for the defence of Ireland was drawn up. This was interpreted in some quarters as handing the Volunteers over to the War Office but that was never Moore's intention. ${ }^{142}$ Redmond maintained that a home defence force would release about 20,000 regular troops for foreign service and would help to inculcate a sense of patriotism and enthusiasm which might lead Volunteers to enlist in due course. In early September he cautioned Birrell that 'if the existing Volunteer organisation is ignored and sneered at and made little of, recruiting in the country will not go ahead' ${ }^{143}$ Unsurprisingly, but to Redmond's dismay, Kitchener, the newly appointed secretary of state for war,

\footnotetext{
${ }^{137}$ Moore to Lt-Col. Daniels, 12 Sept. 1914 (NLI, Moore papers, MS 10,561/6).

${ }^{138}$ Witness statement of Diarmid Coffey (BMH, WS 1,248, 7).

${ }^{139}$ Draft of Moore's statement to the Royal Commission on the Rebellion in Ireland [1916] (NLI, Moore papers, MS 10,572).

${ }^{140}$ MacNeill to Redmond, 9 Aug. 1914 (NLI, MacNeill papers, MS 10,883).

${ }^{141}$ See, for example, Moore to Lord Arran, 18 Aug. 1914 (NLI, Moore papers, MS $10,561 / 1)$.

${ }^{142}$ On this see Hobson, Irish Volunteers, 185-90.

${ }^{143}$ Redmond to Birrell, 9 Sept. 1914 (NLI, Redmond papers, MS 15,169/4).
} 
was hostile to the idea of regularizing and arming the Volunteers for home defence. Uncertainty over the fate of the home rule bill occasioned despondency among the rank and file. The prolonged delay in putting the bill on the statute book on 18 September had, as Redmond later put it, 'a chilling effect'. ${ }^{144}$ By then many Volunteers had grown disheartened and turned away from the organization. The suspension of home rule for the duration of the war accelerated this trend.

\section{The Volunteers split and the formation of the National Volunteers, 1914-16}

Meanwhile tensions had been fermenting on the provisional committee since Redmond's efforts to wrest control. There was strong resistance to the idea of imperial control of the Volunteers. The Irish Party's ambivalence on the matter of recruitment deepened the growing divisions. It appears that the IPP was biding its time before seeking to purge the committee of its more advanced elements. Diarmid Coffey, secretary to Colonel Edmond Cotter, the chief of staff of the Volunteers, recorded in his diary several calls on Redmond to engineer a coup d'état. This had the support of Devlin. ${ }^{145}$ However, there is no evidence to suggest that Moore was a party to this. In a letter to J. J. Horgan on 12 September, Willie Redmond also hinted at a move against the provisional committee by stating that once the home rule bill was on the statute book the "Volunteers will have to be put on a secure footing \& cranks must be faced'. ${ }^{146}$ The degree of coordination shown by MPs in distributing arms to their supporters further suggests that the split was anticipated. ${ }^{147}$ Predictably then, Redmond's speech at Woodenbridge on 20 September, committing the Volunteers to serve 'wherever the firing line extends', fractured the organization. Moore was dismayed. He angrily informed Devlin that 'there should be no reference to recruiting or any such contentious subjects; the country will break away from us if we do'. ${ }^{148}$ He was proved correct.

On 24 September twenty members of the old pre-Redmondite provisional committee issued a statement repudiating 'the claim of

\footnotetext{
${ }^{144}$ Redmond to Sir Reginald Brade, 24 Feb. 1915 (NLI, Redmond papers, MS $15,169 / 4)$.

${ }^{145}$ Entries on 1 and 5 Sept. 1914, diary of Irish Volunteer work by Diarmid Coffey Aug-Dec 1914 (NLI, Coffey and Chenevix Trench papers, MS 46,308/3).

${ }^{146}$ William Redmond to J. J. Horgan, 12 Sept [1914] (NLI, J. J. Horgan papers, MS $18,269)$.

${ }_{147}$ Michael Wheatley, Nationalism and the Irish Party: provincial Ireland, 19101916 (Oxford, 2005), 209.

${ }^{148}$ Moore to Devlin, 28 Sept. 1914 (NLI, Moore papers, MS 10,561/8).
} 
any man to offer up the blood and lives of the sons of Irishmen and Irishwomen to the services of the British Empire while no National Government which could speak and act for the people of Ireland is allowed to exist'. ${ }^{49}$ They seceded and retained the name Irish Volunteers. Pearse, for one, believed the secessionists had 'pulled the Volunteers straight'. ${ }^{150}$ It is impossible to calculate precisely the number of Volunteers that withdrew. It is conventionally believed that the figure was between 11,000 and 13,000 , but this probably exaggerates the actual strength of the Volunteers as a whole in September 1914. The strength of the organization should not be overstated. Many companies existed on paper only and even the more established were poorly trained. The onset of war had dampened the enthusiasm for playing soldiers. The Kerry RIC County Inspector observed in September that waning interest was linked to a 'fear on the part of many members that if they became efficient they would render themselves liable to military service'. ${ }^{151}$ The committee of the Armagh National Volunteers abandoned drill in November for this very reason. ${ }^{152}$ Many Volunteer companies chose not to align with either side and simply ceased to exist. Seán Walsh recalled that there was no split in the Bohola Company in Mayo - it just 'faded away'. ${ }^{153}$ This was quite typical, and such companies were not reformed until 1917 when the Irish Volunteers were reorganized. A tabulation in the Redmond papers indicated that at the end of October over 128,000 Volunteers were classed as undecided. That 120,000 of these were deemed Redmondite was cold comfort. ${ }^{154}$

Moore was in an agonizing position. Bound by ties of friendship and council to both groups, he had tried 'to soften the asperities' with which each regarded the other in a vain attempt to prevent an open rupture. His soldier's professional inclination to duty proved decisive. In a carefully worded letter to the press dated 26 September he suggested that every Irishman - unionist and nationalist - would regret the division of the 'great organisation which we have laboured so hard to construct and which has accomplished so much in so short

\footnotetext{
${ }^{149}$ Statement by provisional committee on split with Redmond, 24 Sept. 1914 (NLI, Hobson papers, MS 13,174/10).

${ }^{150}$ Pearse to Joe McGarrity, 26 Sept. 1914 (ibid., MS 13,162).

${ }^{151}$ Kerry County Inspector confidential report for Sept. 1914 (TNA, CO 904/94).

${ }^{152}$ RIC Inspector-General's monthly report for Nov. 1914 (TNA, CO 904/95).

${ }^{153}$ Witness statement of Seán Walsh (BMH, WS 1,733, 2).

154 'Table showing the original strength of the Irish National Volunteers and indicating approximately how the various battalions divided as result of meetings held from 24 September, date of secession, up to and including 31 Oct. 1914' (NLI, Redmond papers, MS 15,258).
} 
a time'. ${ }^{155}$ Arguing that the Volunteers would ultimately have to come under the control of the anticipated Irish government, he placed his services 'at the disposal of the leader of the Irish people'. ${ }^{156}$ Moore did not mention Redmond by name. Yet the leader of the IPP read the letter 'with great pleasure' and probably no little relief. He believed that Woodenbridge had detoxified the Volunteers and suggested to Moore that as long as the malcontents remained 'no practical work could be done to put the Volunteer organisation on a real business basis' ${ }^{157}$ In the following days and weeks Moore received many letters of support. One captain in the Ballinasloe Battalion wrote: 'we are solid for you and Mr Redmond'. ${ }^{158}$ Intriguingly, Moore retained lingering hopes of reuniting the two Volunteer factions to the extent that in February 1915 Joseph Devlin expressed doubt on his being wholeheartedly with the IPP. ${ }^{159}$ One statement to the Bureau of Military History recalled Moore attending an unsuccessful reunification meeting with Irish Volunteers in Tralee. ${ }^{160}$

The split severely damaged the National and Irish Volunteers. Both were and remained quite Dublin-centred. They faced considerable common challenges: putting in place a functioning headquarters structure; electing county boards, composed of delegates from each company; holding a Volunteer convention; devising and promulgating a constitution; assessing the strength of existing companies; deciding membership rules; collecting affiliation fees; publishing a weekly newspaper; and training and equipping companies. The Irish National Volunteers were launched at a meeting in Dublin City Hall on 30 September, at which Redmond was unanimously elected chairman. Retaining the original motto 'defence not defiance', the stated purpose of the new organization was 'to train, equip and arm a Volunteer force for the defence of Ireland and the advancement and preservation of Irish rights and the maintenance of Irish National self-government'. ${ }^{161}$ The National Volunteers were run from offices located initially at 16 South Frederick Street and from January 1915 at 44 Parnell Square, the new central headquarters, by a national committee of thirty members but only Dublin members attended with any regularity. The insurmountable difficulty for the National

\footnotetext{
${ }^{155}$ Moore to editor of the Irish Independent, 24 Sept. 1914 (published on 26 Sept.).

${ }^{156}$ Ibid; Denis Gwynn, The life of John Redmond (London, 1932), 392.

${ }^{157}$ Redmond to Moore, 26 Sept. 1914 (NLI, Moore papers, MS 10,561/34).

${ }^{158}$ Capt J. T. Greeves O'Sullivan to Moore, 3 Oct. 1914 (ibid., MS 10, 561/2).

${ }^{159}$ Memorandum of interview with Joseph Devlin, 20 Feb. 1915 (Bodleian Library, Nathan papers, MS Nathan 467 ff. 155-6).

${ }^{160}$ Witness statement of Tadhg Kennedy (BMH, WS 1,413, 17).

${ }^{161}$ Minutes of meeting of national committee, 14 Oct. 1914 (NLI, Moore papers, MS 9,239).
} 
Volunteers was that they were bound tightly to Redmond's faltering war policy. The national committee was also guilty of profligate financial management and frittered away the start-up fund of over $£ 5,000$ raised by Redmond. ${ }^{162}$ Its minutes also reveal a lack of urgency, an obsession with procedure, deference to Redmond's wishes and, most conspicuously, a curious silence on military matters beyond the urgings of its honorary secretaries (John T. Donovan MP and Laurence Kettle) from October 1914 onwards for companies to appoint committees and county boards.

Moore was appointed inspector-general with 'supreme command of the military council' but he encountered major problems. ${ }^{163}$ The government's inaction exasperated him and dispirited the rank and file. 'Affairs seem to me to be in a very extraordinary condition' he wrote to Devlin: 'We had this talk about Irish Brigades etc. but the military authorities have taken no steps to start them ... What are the authorities at? Is Asquith working one way and Kitchener another?"164 Moore was unable to galvanize the national committee to act and he was thwarted by its parsimony, prevarication, penchant for postponement and proclivity to refer issues to sub-committees. As a result the holding of a national convention and the finalization of a constitution were continually postponed. A planned headquarters staff comprising chief inspectors of organization, inspection, instruction and arms, never came to fruition. ${ }^{165}$ At the end of October a despondent Moore complained to Redmond: 'I have been trying to get some practical work begun since the split and find myself not one inch advanced'. ${ }^{166}$ This was replicated throughout the organization. At an officer training camp in Limerick in October - one of two such gatherings (the second took place in January 1915) - it was reported that 'All the officers ... were restive and grumbling at the standstill in the Volunteers' ${ }^{167}$ In his report for December 1914, the RIC inspector-general commented 'there is at present no enthusiasm in this force, which has neither organisation, nor officers, is utterly untrained and practically unarmed' ${ }^{168}$

With little prospect of the Volunteers becoming a recognized territorial force, many officers sought a commission in the army in late 1914. Moore himself contemplated resigning in early November given the desire of the national committee to have the military

\footnotetext{
${ }^{162}$ Arthur Ryan (trustee) to treasurers INV, 15 Apr. 1915 (ibid., MS 10,569).

${ }^{163}$ Minutes of meeting of national committee, 30 Sept. 1914 (ibid., MS 9,239).

${ }^{164}$ Moore to Devlin, 28 Sept. 1914 (ibid., MS 10,561/8).

${ }^{165}$ Memo on headquarters staff, 12 Oct. 1914 (ibid., MS 10,544/12).

${ }^{166}$ Moore to Redmond, 29 Oct. 1914 (ibid., MS 10,561/34).

${ }^{167}$ J. J. Holland to Moore, 12 Oct. 1914 (ibid., MS 10,561/19).

${ }^{168}$ RIC Inspector-General's monthly report for Dec. 1914 (TNA, CO 904/95).
} 
THE CAREER \& CONTRIBUTION OF COL. MAURICE MOORE, 1854-1939 101

department 'squashed out' and the reluctance of the IPP leadership to support his efforts. ${ }^{169}$ His mood was hardly improved by a letter from Alice Stopford Green, the historian, who on meeting Redmond in London, found him 'entirely jubilant over the Volunteers, and entirely ignorant! ... His whole interest is set on getting the men into the army and he does not give any thought at all to those who remain in the country'. ${ }^{170}$ That was only partly true. Despite the indifference of the War Office, the IPP continued throughout 1915 to pin its hopes on the National Volunteers being accepted for home defence on the same basis as territorials.

The home defence concept seemed to gain traction in December 1914 when the Cork National Volunteers offered to assist the military and police by guarding waterworks and railway bridges. This gesture was widely commended. The National Volunteer published a wire from Redmond: 'trust War Office will now utilise force generally for defence purposes everywhere.' ${ }^{171}$ Fitzroy Hemphill, Moore's assistant, reported encouragingly:

The moral effect both in England and in Ireland of the assumption of guard duties by the Cork Battalion has been very great. It is very important that the National Volunteers should have public opinion in England disposed in their favour so that pressure may be brought to bear upon the War Office and the Government to recognise the Volunteers by utilising their services.

It will greatly help recruiting for the Volunteers if the men themselves feel that they are really doing military duty and not merely playing at soldiering. ${ }^{172}$

To ordinary Volunteers it offered the prospect of meaningful semi-military work. Indicatively, the Inishowen National Volunteers came forward in February 1915 with the suggestion that they would undertake coastal defence duties. Matthew Nathan, the undersecretary, was disposed to agree but the military authorities would only accede if the Volunteers agreed to serve as unarmed special constables. ${ }^{173}$ The national committee in Dublin objected. In March 1915 the idea of putting the National Volunteers on the same footing

\footnotetext{
${ }^{169}$ Moore to Devlin, 7 Nov. 1914 (NLI, Moore papers, MS 10,561/8).

${ }^{170}$ Alice S. Green to Moore, 19 Nov. 1914 (ibid., MS 10,561/17).

${ }^{171}$ National Volunteer, 9 Jan. 1915.

${ }^{172}$ Hemphill to honorary secretaries INV, 5 Feb. 1915 (NLI, Moore papers, MS $10,545 / 7)$.

${ }^{173}$ Memorandum of interview with Generals Friend and Greenfield, 6 Feb. 1915 (Bodleian Library, Nathan papers, MS Nathan 467 ff 144-8).
} 
as territorials in Britain was favoured by Asquith but strongly opposed by the War Office. ${ }^{174}$ This killed off the idea and consequently did great damage to the National Volunteers as ordinary members began to question the purpose of continued involvement. By extension, Redmond's strategy was also undermined. He had anticipated that if Volunteers enlisted for home service and did practical work connected with their district then volunteers for military service abroad would inevitably follow. ${ }^{175}$ Despite the machinations of the War Office, some 29,928 National Volunteers (both reservists and recruits) had joined the colours by mid-March 1916. Redmond received neither thanks nor credit for this impressive result which was marginally in excess of the 29,505 Ulster Volunteers who joined up; some 56,472 men not known to be members of either force also joined giving a combined total of $115,905 .{ }^{176}$

Another reason for declining membership of the National Volunteers was the unavailability of arms. Many rank and file Volunteers saw little point in participating if weapons were not forthcoming. In January 1915 Neville Chamberlain, the RIC inspector-general, observed that the National Volunteers were 'practically unarmed'. It was estimated that they held about 10,128 rifles compared to the 53,985 in the hands of the UVF and 1,438 in the possession of the Irish Volunteers. ${ }^{177}$ The acquisition, and distribution, of arms was debated at length by the national committee, and Redmond was subject to relentless pressure to solve the problem. For example, in June 1915 the secretary of the Limerick City National Volunteers warned that the rank and file eagerly awaited rifles and that 'a disappointment of their expectations might lead to a thinning of their ranks'. ${ }^{178}$ This was not being alarmist, as police reports indicated that the National Volunteers were 'steadily on the decline'. ${ }^{179}$ Although serviceable weapons were in short supply because of wartime demand, Redmond was able to import obsolete weapons not required by the military authorities under permit using a highly convoluted system of personal intermediaries, which included Asquith, the under-secretary of state for war, the master-general of

\footnotetext{
${ }^{174}$ Nathan to Birrell, 22 Mar. 1915 (ibid., MS Nathan 462 ff 671-2).

${ }^{175}$ Memorandum of interview with John Redmond, 4 Feb. 1915 (ibid., MS Nathan $467 \mathrm{ff} 133-40)$.

176 'Estimate of the number of reservists and recruits who have re-joined or joined from Ireland since the outbreak of War up to 15 March 1916 classified as National Volunteers, Ulster Volunteers and others' (NLI, Redmond papers, MS 15,259).

${ }^{177}$ RIC Inspector-General's monthly report for Jan. 1915 (TNA, CO 904/96).

${ }^{178}$ Cornelius Cregan (Hon Recording Sec. Limerick City Regiment National Volunteers) to Redmond, 7 June 1915 (NLI, Redmond papers, MS 15,261/4).

${ }^{179}$ RIC Inspector-General's monthly report for Apr. 1915 (TNA, CO 904/96).
} 
the ordnance, the general officer commanding London, the chief secretary for Ireland, Nathan, and the general officer commandingin-chief the forces in Ireland. ${ }^{180}$ This importation generated as many difficulties as it solved. There were countless delays, with the result that the request from Limerick was only fulfilled at the end of October. ${ }^{181}$ Furthermore, there were never enough rifles, and securing obsolete ammunition for archaic weapons proved almost impossible.

The military authorities were understandably anxious that arms were stored safely and that they remained in proper hands. They were unpersuaded by reassurances from Redmond that rifles delivered to Kettle or Moore were 'quite safe, and are for our Volunteers, and are in no danger of being misused. ${ }^{182}$ Concerns were intensified by the embarrassing theft of rifles destined for the National Volunteers in November 1914 and again in mid-August 1915. ${ }^{183}$ Throughout 1915 the Irish administration worried, quite rightly, about the possibility of arms raids by members of the Irish Volunteers. A DMP constable was put on night duty at 44 Parnell Square, and in December 1915 a second policeman was assigned to the lane at the back of the building. ${ }^{184}$ A related concern was that arms were sold to Volunteers in the provinces without appropriate enquiry as to the suitability of the purchaser. As a result, questions were raised not only by the military authorities but also by senior members of the IPP such as Devlin as to Moore's control over the National Volunteers and loyalty to Redmond. ${ }^{185}$

In addition to the supply of arms, the efficacy of the National Volunteers was inhibited by waning enthusiasm, a shortage of instructors, organizers, funds, and information on unit strength. Of 1,179 forms sent out to company secretaries in January 1915 only sixty were returned. ${ }^{186}$ The financial receipts of the national committee painted a similarly bleak picture. In December 1914 monies received for registration fees, membership cards, enrolment forms, and arms and ammunition came to over $£ 228$; twelve months

\footnotetext{
${ }^{180}$ Nathan to Major-General L.B. Friend, 12 May 1915 (TNA, CO 904/29/2).

${ }^{181}$ Cregan to Redmond, 31 Oct. 1915 (NLI, Redmond papers, MS 15,261/8).

${ }^{182}$ Redmond to Nathan, 8 Feb. 1915 (Bodleian Library, Nathan papers, MS Nathan 460 f. 91).

${ }^{183}$ Memorandum of interview with Colonel Maurice Moore, 28 Nov. 1914 (ibid., MS Nathan 467 ff 46-7); Irish Times, 16 Aug. 1915.

${ }^{184}$ Walter Edgeworth-Johnstone (DMP commissioner) to Nathan, 14 Dec. 1915 (Bodleian Library, Nathan papers, MS Nathan 455 ff 23-4).

${ }^{185}$ Memorandum of interview with Joseph Devlin, 20 Feb. 1915 (Bodleian Library, Nathan papers, MS Nathan 467 ff 155-6).

${ }^{186}$ Report by Fitzroy Hemphill to the hon. secretaries INV, 30 Jan. 1915 (NLI, Moore papers, MS 10,545/7).
} 
later the sum received amounted to just $£ 2315 s .{ }^{187}$ Likewise, sales of the National Volunteer newspaper, which was more interested in political propaganda than military matters, declined sharply in the same period. This was further evidence, if any was needed, of the general withering of the National Volunteers. So grave was the financial position of the National Volunteers that in July 1915 an auditors' report suggested replacing one of Moore's military staff with a lady typist - a bizarre economy for a supposedly semi-military body. Moore railed against 'reckless expenditure on newspapers' and the efforts of the national committee to usurp military powers. He warned starkly that if the National Volunteers fail 'in its military aspect, it fails altogether'. ${ }^{188}$

In March 1915 the honorary secretaries claimed upwards of 900 registered National Volunteer companies with a total membership of between 120,000 and 150,000 men. ${ }^{189}$ In reality the organization had not only lost all momentum but had atrophied. Numerous requests for speakers and organizers in early 1915 flattered to deceive, as they arose out of a decision to hold a national review at Easter 1915, which involved Moore in an arduous and bad-tempered battle with the national committee. The review was attended by an estimated 20,000 Volunteers. According to Robert Barton, who had managed the Irish Volunteers military office before accepting a commission in the Royal Dublin Fusiliers, without Moores involvement it 'would have been a dismal failure'. ${ }^{190}$ The review was superficially impressive, and belied a belief (or perhaps just the hope) that a show of organizational zeal would persuade truant members to return. They certainly did but only for the day, as the RIC inspector-general noted in April that 'apathy' was everywhere noticeable in the diminishing Volunteer movement. By contrast, he believed the 'Sinn Féin section' to be better organized and making more progress in the direction of efficiency though not increasing numerically. ${ }^{191}$ Indicatively, many rifles issued to National Volunteers were never returned because members dropped out or defected to the Irish Volunteers.

The dutiful Moore continued to journey from county to county tirelessly attending reviews, performing inspections and rousing lapsed companies until the summer of 1915. In June he admitted

\footnotetext{
${ }^{187}$ Minutes of meeting of national committee, 8 Dec. 1914 and 7 Dec. 1915 (ibid., MS 9,239).

${ }^{188}$ Moore to honorary secretaries INV, 6 July 1915 (NLI, Redmond papers, MS 15,206/7).

${ }^{189}$ Report of honorary secretaries INV, 31 Mar. 1915 (NLI, Moore papers, MS 10,545/7).

${ }^{190}$ Barton to Moore, 30 Apr. 1915 (NLI, Moore papers, MS 10,561/2); witness statement of Robert Barton (BMH, WS 979, 8).

${ }^{191}$ RIC Inspector-General's monthly report for Apr. 1915 (TNA, CO 904/96).
} 
THE CAREER \& CONTRIBUTION OF COL. MAURICE MOORE, 1854-1939 105

that he had had 'a dose of speeches, inspections and travelling'. ${ }^{192}$ His efforts were paralleled by those of Captain John Eckersley who visited Counties Cavan, Tyrone, Tipperary, Limerick and Clare. But success was at best ephemeral. There are grounds for believing that Eckersley was dispatched to those areas in an effort to counteract the efforts of rival Irish Volunteer organizers. The national committee had neither the interest nor the money to undertake a proper system of organization. As a result, Moore was an increasingly forlorn figure in the second half of 1915. By September he believed 'nothing can be done with the Volunteers ... they cannot be trained disciplined or armed; moreover the enthusiasm has gone and they cannot be kept going ... It has exhausted its usefulness'. ${ }^{193}$

The decline of the National Volunteers encouraged Moore to contemplate re-entering military service. Both Nathan and MajorGeneral L. B. Friend of the Irish Command thought it 'would be a good thing if his activity were taken up by proper military work' such as command of a reserve battalion of the 16th Division. ${ }^{194}$ Nathan revealed that John Dillon 'would be delighted if this can be arranged. Moore is rather a thorn in their [IPP's] side and they distrust his judgement'. The under-secretary opined that Moore 'will be quite good when he again comes under the military system in which he spent a large part of his life'. ${ }^{195}$ There was also a financial consideration. With only an army officer's pension, Moore was under increasing financial pressure as a consequence of maintaining a house in London but living in Dublin for Volunteer work for which he refused to accept payment. In addition, while there can be no doubting Moore's commitment to the Volunteers, he retained a deep interest in the war effort through membership of the All Ireland Munitions Committee and as chairman of a society for sending relief to prisoners of war in Germany. By early 1916, with home rule shelved, the political rationale for the Volunteer movement was no longer compelling. As a result Moore concluded that the war was 'more urgent than those [duties that] I am obliged to relinquish'. ${ }^{196}$ The fact that his sons and two nephews had joined the colours provided further motivation. Ulick, who served with the 6th Connaught Rangers, was later killed at Sainte-Émilie in March 1918. For a variety of reasons therefore

\footnotetext{
${ }^{192}$ Moore to Coffey, 27 June 1915 (NLI, Moore papers, MS 10,561/2).

${ }^{193}$ Moore to Redmond, 24 Sept. 1915 (NLI, Redmond papers, MS 15,206/7).

${ }^{194}$ Nathan to Birrell, 2 Sept. 1915 (Bodleian Library, Birrell papers, MS Eng. c. $7033 \mathrm{ff} 187-8)$.

${ }^{195}$ Nathan to Birrell, 3 Sept. 1915 (Bodleian Library, Nathan papers, MS Nathan 464 ff 398-400).

${ }^{196}$ Moore to secretaries INV, 1 Mar. 1916 (NLI, Moore papers, MS 10,546/1).
} 
Moore applied to the national committee in March 1916 for leave of absence for twelve months. ${ }^{197}$ This was granted, probably with some relief, and Colonel James Crean deputized as acting inspector-general of the National Volunteers. Moore was immediately employed as garrison commander of Bere Island. This appointment lasted for only six weeks and was brought to a swift end by the 1916 Rising. In May the War Office directed that only officers on the active list should be given commands. ${ }^{198}$ Forced to stand down, Moore believed the order was 'in pursuance of the clearing of Sinn Féiners out of employment. In army eyes Nationalists are Sinn Féiners'. ${ }^{199}$

\section{The aftermath of the 1916 Rising, 1916-19}

Moore was not immune from the sea change in public opinion occasioned by the British government's ill-judged responses to the 1916 Rising. But his was, by any standards, a remarkable journey. When attempts to re-establish the National Volunteers were thwarted he terminated his relations with the hapless windbags on the national committee and reunited with the Irish Volunteers. The Volunteers were not his sole concern. He contributed to a variety of topical issues ranging from partition to the campaign to secure a reprieve for Roger Casement, and floated a scheme for dominion status. Characteristically, his views were considered and in many cases quite prescient. One correspondent praised Moore's prudence, patriotism and 'sage advice' in his public addresses and letters. ${ }^{200}$

Moore was dismayed at the government's response to the Rising and disheartened by the IPP's stance. He submitted an unflinching written statement to the Royal Commission on the Rebellion but it was not made public. ${ }^{201}$ Moore cited two primary reasons for the outbreak. First, Irish nationalism was roused by the violence of the Ulster agitation against home rule. Second, the government temporized fatally on the question of home rule while still demanding recruits and rejecting every proposal regarding the Volunteers. This strengthened the Sinn Féin element, embittered Irish public opinion and led Moore to conclude that 'distrust of English good faith is the basis of Irish disloyalty' ${ }^{202}$ Nationalists, irrespective of political hue,

\footnotetext{
${ }^{197}$ Minutes of general purposes committee INV, 28 Mar. 1916 (ibid., MS 9,241); Kettle to Moore, 1 Apr. 1916 (ibid., MS 10,561/18).

${ }^{198}$ L. B. Friend (HQ Irish Command Parkgate Dublin) to Moore, 14 May 1916 (ibid., MS 10,561/15).

${ }^{199}$ Moore to Redmond, May 1916 (ibid., MS 10,561/34).

${ }^{200}$ Bishop Bernard Coyne to Moore, 13 July 1916 (ibid., MS 10,564/1).

${ }^{201}$ Irish Times, 30 May 1916.

${ }^{202}$ Draft of Moore's statement to the Royal Commission on the Rebellion in Ireland, [May 1916] (NLI, Moore papers, MS 10,572).
} 
THE CAREER \& CONTRIBUTION OF COL. MAURICE MOORE, 1854-1939 107

instinctively disliked seeing rebels shot or imprisoned by the British government and, in tune with this growing sentiment, Moore praised the character and patriotism of the executed as 'men whose whole lives from childhood had been permeated with thoughts not of their own selfish interests, but of the interests of their country... men who would have been the finest and choicest blossom of any Nation in the world' ${ }^{203}$ Unsurprisingly, Moore supported the efforts of the Irish National Aid Association to provide relief to sufferers following the disturbances. Elected to its executive, he issued a plea to the National Volunteers to make a collection in support of the Association: 'it is our duty to do something more than mourn ... to see that those who have been left behind shall not suffer cold or hunger. ${ }^{204}$ The National Volunteers were happy to gather and transfer any contributions but Redmond, notably, did not want his name associated with the appeal. ${ }^{205}$

With Agnes O'Farrelly, lecturer in Irish at UCD and prominent member of the executive committee of the Gaelic League, Moore organized a petition for the reprieve of Roger Casement in July 1916. This was one of several such efforts by prominent public figures who numbered the archbishop of Canterbury, Arthur Conan Doyle and George Bernard Shaw among their ranks; the latter argued that Casement would be regarded as a national hero in Ireland only if he was executed. ${ }^{206}$ Conscious of the depth of feeling against Casement's perceived treachery, particularly in Britain, Moore and O'Farrelly's petition was not made public lest it be misconstrued as a statement of support for Casement's actions; rather, it was a plea against any further bloodshed. ${ }^{207} \mathrm{In}$ a forceful letter to the prime minister, Moore claimed that the shooting of the rebels was a source of the "most deplorable revulsion of feeling that has ever occurred in Ireland', and warned of the dire consequences and 'enduring feeling of hate' of another execution. 'Be wise', he urged, 'stop this execution; if

\footnotetext{
${ }^{203}$ Ibid.

${ }^{204}$ Louisa Gavan Duffy, Fred Allan, Michael Davitt, Thomas J. Cullen (honorary secretaries, Irish National Aid Association) to Moore, 3 June 1916 (NLI, Moore papers, MS 10,558/2); Appeal to the Irish National Volunteers, [June 1916] (NLI, Art Ó Briain papers, MS 8455/3).

${ }^{205}$ T.J. Hanna to Moore, 13 June 1916 (NLI, Moore papers, MS 10,561/16); Minutes of a special meeting of national committee, 28 June 1916 (NLI, Moore papers, MS 9,239 ).

${ }^{206}$ See Brian Inglis, Roger Casement (London, 1973), 353-4; Roger Casement in Irish and world history: proceedings of a symposium 5th and 6th May 2000 held at the Royal Irish Academy (Dublin, 2000), 16.

${ }^{207}$ Circular by Roger Casement reprieve committee, 17 July 1916 (NLI, Moore papers, MS 10,564/1); Denis Gwynn, The life and death of Roger Casement (London, 1930), 422.
} 
not take a terrible responsibility on yourself.' ${ }^{208}$ Others such as W. B. Yeats believed that a pardon would mollify public opinion and allow 'moderate opinion in Ireland to recover something of its weight' ${ }^{209}$ The petition was circulated selectively to prominent individuals. Encouraged by Alice Stopford Green, Moore attempted to elicit the support of the Catholic bishops. By the end of July eighteen prelates (including the archbishops of Armagh and Dublin), two peers, twentysix MPs and 247 prominent individuals had signed the petition in the earnest hope "that the calamity to both Ireland and England of this final execution may yet be averted' ${ }^{210}$ Their efforts were in vain. The discovery of Casement's diaries detailing his homosexual activities, extracts of which were circulated, proved decisive and allowed the British cabinet to ignore all entreaties, including two resolutions from the US. ${ }^{211}$ Casement was hanged on 3 August 1916.

Although the Rising induced a fresh (if ultimately futile) attempt to bring about a home rule settlement, Moore grew increasingly sceptical of the IPP's position. On 24 May David Lloyd George, then minister for munitions, was commissioned to negotiate an arrangement to bring into operation as soon as possible the Home Rule Act of 1914 with the exclusion of the six counties. Northern nationalists reacted with alarm when the proposals became public knowledge in early June. To the Irish Independent, the most widely read national daily, home rule for twenty-six counties was an 'abomination' and several editorials were devoted to opposing 'the mutilation and dismemberment of the Irish nation'. ${ }^{212}$ It was not surprising then that Moore raised the home rule proposals at a special meeting of the national committee of the National Volunteers on 17 June. He was adamant that the Volunteers should not countenance any exclusion, temporary or permanent, of any part of Ireland. From a strategic perspective, he believed that the establishment of a parliament in Dublin before the end of the First World War would leave nationalists better placed to bring all of Ireland under one government and improve the restrictive financial clauses of home rule at the end of the conflict. He also wanted to link any acceptance of the home rule proposals with an amnesty for political internees. ${ }^{213}$

\footnotetext{
${ }^{208}$ Moore to Asquith, 29 July 1916 (ibid., MS 10,561/1).

${ }^{209}$ Yeats to Asquith, 14 July 1916 (ibid., MS 10,564/1).

${ }^{210}$ Moore and O'Farrelly to Asquith, 29 July 1916; copy of petition (NLI, Moore papers, MS 10,564/4).

${ }^{211}$ Inglis, Casement, 358-70.

${ }^{212}$ Irish Independent, 8 June 1916.

${ }^{213}$ Minutes of special meeting of national committee, 17 June 1916 (NLI, Moore papers, MS 9,241). See also Moore to unnamed respondent, 8 Nov. 1916 (ibid., MS $10,571 / 3)$.
} 
Predictably, the national committee deemed such political comment out of order. The failure of the Lloyd George scheme and acceptance of partition did irreparable damage to the IPP, something clearly recognized by Moore. 'The country is in as bad a state as it was at the time of the Parnell split', he explained to Shane Leslie, then in America, 'complete confidence in the party and leaders is gone... the ideals of Irish Ireland existed only among a few, but the rebellion and more than the rebellion - the shootings - have spread them far and wide. The parliamentary party have never understood these ideals and are too old to do so now' ${ }^{214}$ Six months later he wrote to John Dillon, leader of the IPP and MP for Mayo, of the state of feeling in that county and the growing ascendancy of Sinn Féin. Both young and seasoned voters had lost confidence in the IPP and its policies: 'if something decisive be not done the revolution may go to the extreme of changing the whole party, leaders and all.'215 This signalled Moore's break with the party and a gradual but never complete embrace of Sinn Féin policy.

Moore joined a Sinn Féin club in County Mayo in September 1917, but he was not a doctrinaire republican. ${ }^{216}$ Informed by the examples of Canada and South Africa as self-governing dominions, his was a more pragmatic conception of Irish self-government. In a number of public letters, both before and after the Rising, he called for political reflection and a fresh consideration of the challenges facing Ireland. In March 1917 Moore was a key member of a non-partisan group - with, among others, Edward MacLysaght, George Russell (Æ), James Douglas and Diarmid Coffey - which produced a thirty-two point memorandum 'concerning the present and future relations of Great Britain and Ireland in the Empire'. ${ }^{217}$ The document rejected the third home rule bill because it would 'not satisfy or pacify Ireland' and instead recommended dominion selfgovernment on an all-Ireland basis. It commented also on various economic, fiscal, legislative, constitutional and defence issues. But

${ }^{214}$ Moore to Leslie, 7 Sept. 1916 (ibid., MS 10,561/22).

${ }^{215}$ Moore to Dillon, 4 Mar. 1917 (ibid., MS 10,561/9).

${ }^{216}$ Moore to Edward MacLysaght, 21 Sept. 1917 (NLI, MacLysaght papers, MS $2,650)$.

${ }^{217}$ See J. Anthony Gaughan (ed.), Memoirs of Senator James G. Douglas (18871954): concerned citizen (Dublin, 1998), 54; 'Memorandum concerning the present and future relations of Great Britain and Ireland in the Empire', 5 Apr. 1917 (NLI, Moore papers, MS 10,574). The signatories of the memorandum were George Russell, James Douglas, Alec Wilson, Edward MacLysaght, Dermot Coffey, John Mackie, Sir Algernon Coote, Sir Nugent Everard, Sir John O'Connell, James MacNeill, Joseph Johnson, Professor E. Curtis, Major James Crean and Moore. MacLysaght claimed that the initiative for the document came from a letter that he circulated, see MacLysaght, 'Master of none', chapter 8 (NLI, MacLysaght papers, MS 4,750). 
the memorandum's real significance lay in its frank analysis of the exploitation of the Ulster question by English Conservatism. It suggested that the Imperial Conference could bring 'various and opposing views towards a common focus' and ultimately envisaged a self-governing Ireland within a 'federation of the Empire'. ${ }^{218}$ Moore believed strongly that Ireland should be represented at the Imperial Conference assembled in London between 21 March and 27 April 1917. He moved a motion to this effect at a meeting of the national committee of the National Volunteers. ${ }^{219}$ The dominion proposal and its promotion were the subject of a meeting in Allen's Hotel, 70 Harcourt Street on 5 April organized by Moore, Æ and Douglas. Copies of the memorandum were dispatched to prominent individuals and politicians in Britain and Ireland, including Lloyd George. 'My committee', Moore wrote to the prime minister, 'has good reason to believe that the memorandum expresses the opinion of that great body of Irish opinion which is not fully represented by either the Irish Nationalist or Unionist Party in the House of Commons. ${ }^{220}$ The following week Moore, Douglas and $Æ$ travelled to London, where they were assisted by Alice Stopford Green. Of their various interviews with politicians and journalists, Douglas recalled that Sir John Simon, the former Liberal home secretary, 'appeared to take our proposals seriously'. ${ }^{221}$ The memorandum was also shown to General Jan Smuts. It appears to have been one of several stimuli behind the government's decision in May 1917 to call an Irish Convention, which convened between 25 July 1917 and 5 April $1918 .{ }^{222}$ In response, $Æ$ re-wrote the memorandum under the heading 'Thoughts for a Convention: a memorandum on the state of Ireland'. This was published in three instalments in the Irish Times at the end of May 1917 and received significant support from the likes of William Walsh, archbishop of Dublin and Lord Monteagle. ${ }^{223}$ Three of the original authors - Æ, Coffey and MacLysaght - became members of the Irish Convention to which Moore contributed a memorandum on defence and financial relations between Britain and Ireland. ${ }^{224} \mathrm{He}$ continued to promote a federated empire and predicted

\footnotetext{
218 'Memorandum concerning the present and future relations', paragraphs 17, 32.

${ }^{219}$ Donovan to Redmond, 20 Mar. 1917, enclosing copy of Moore's resolution (NLI, Redmond papers, MS 15,185).

${ }^{220}$ Moore to Lloyd George, 5 Apr. 1917 (NLI, Moore papers, MS 10,574).

${ }^{221}$ Gaughan (ed.), Memoirs, 55.

${ }^{222}$ For a discussion of the varied origins of the convention idea, see Alvin Jackson, Home rule: an Irish history, 1800-2000 (London, 2004), 206.

${ }^{223}$ Irish Times, 26, 28 and 29 May 1917; Monteagle to Edward MacLysaght, 12 June 1917 (NLI, MacLysaght papers, MS 2650); Gaughan (ed.), Memoirs, 56-7.

${ }^{224}$ Memorandum by Moore 'Defence of Ireland and Financial Relations', [1917?]
} 
that the dominions could not remain subordinate to the imperial parliament. Almost a decade later this is what transpired with the Balfour Declaration in 1926 and the Statute of Westminster five years after that. ${ }^{225}$

Despite their increasing marginality, Moore remained deeply committed to the ailing National Volunteers, loyal to its constitution and concerned for the rank and file. In the weeks and months after the Rising the key question for him was not if but how the organization would be carried on. He pointed out to Devlin that the Volunteers could have a positive influence 'but we must be allowed to go our own way. Delaying and blocking our movement will do no good either to the Volunteers or the Party or the cause'. ${ }^{226}$ In the same letter Moore claimed that some members of the party were 'spreading lies' about him. The civil and military authorities and the leadership of the IPP were united in their opposition to any resuscitation of the National Volunteers. Martial law, which remained in operation until the end of 1916, made this improbable as public meetings and drilling were prohibited. Undeterred, Moore made a number of efforts to reactivate the Volunteers in June 1916. A request to General Sir John Maxwell, commander-in-chief in Ireland following the Rising, to permit meetings for miniature rifle practice was flatly rejected. ${ }^{227}$ Moore persisted and in early July appealed to the general to reconsider the position regarding private drilling and shooting practice. He asked specifically for the return of arms and ammunition which had been lent by the National Volunteers to the military and police during the rebellion on the promise that it would be returned. He pointed out that the National Volunteers had demonstrated their loyalty during the rebellion but were rewarded by 'being practically suppressed afterwards', and he observed ominously, 'It will not be surprising if many of them turn their eyes towards the Sinn Féiners'. ${ }^{228}$ Maxwell in response patronisingly advised Moore to take his 'instructions in these matters from your political leader'. No timeframe was indicated for the return of arms but Maxwell did at least indicate that he had 'no intention of breaking faith with the lenders'. 229 Predictably, sanction for private drilling was withheld as the National Volunteers were not recognized by the War Office. Even the practice of Swedish

(NLI, Moore papers, MS 10,573); Moore to MacLysaght, 21 Sept. 1917 (NLI, MacLysaght papers, MS 2650).

${ }^{225}$ See, for example, Moore to the editor of the Freeman's Journal, 3 July 1917 (published 7 July).

${ }^{226}$ Moore to Devlin, 12 June 1916 (NLI, Moore papers, MS 10,561/8).

${ }^{227}$ HQ Irish Command to Moore, 19 June 1916 (NLI, Moore papers, MS 10,561/29).

${ }^{228}$ Moore to Maxwell, 7 July 1916, ibid.

${ }^{229}$ Maxwell to Moore, 10 July 1916, ibid. 
drill, a form of Edwardian aerobics, was deemed illegal and Moore was duly cautioned by the military authorities. ${ }^{230}$ In a revealing letter to Henry Duke, the chief secretary, Maxwell was adamant that 'any recrudescence of the National Volunteers is to be deprecated' lest it exacerbated recruiting difficulties for the army, and because 'it would be weak and unwise to withdraw the restrictions regarding drill parades and rifle practice' ${ }^{231}$ By October, weary of government inaction, Moore complained of breach of promise over the return of arms: 'the lack of faith in Government pledges has more to do with discontent in Ireland than anything I know of', he pointed out. ${ }^{232}$ The arms were belatedly returned in January 1917 .

The question of holding a convention to discuss the future of the National Volunteers dominated the closing months of 1916. The organization's constitution stipulated that a convention be held at least once every two years. The last was on Easter Monday 1915 and none was possible in 1916. At a special meeting of the national committee on 12 September Moore proposed that a convention be summoned no later than the second week in December. ${ }^{233} \mathrm{~A}$ subsequent circular to Volunteer companies alarmed the authorities by exhorting members to reorganize and send on their affiliation fee because 'the times are threatening and vast national issues of the first importance loom up in the immediate future. We must organise, strengthen, and consolidate our forces'. ${ }^{234}$ The most pressing issue was the very real threat of conscription, something Moore believed would be everywhere resisted due to the broken promises of English politicians. ${ }^{235}$ The conscription danger galvanized the efforts of the honorary secretaries of the National Volunteers. In mid-October they again urged that the Volunteers be immediately reorganized and 'pledged to resist conscription', lest it be enforced by the government while 'they believe the country is in a disorganised condition' ${ }^{236}$ It was also proposed to distribute recruiting posters for the National Volunteers around the country. ${ }^{237}$ To the press censor

\footnotetext{
${ }^{230}$ Minutes by the under-secretary, 14 and 15 Dec. 1916 (TNA, CO 904/122/1).

${ }^{231}$ Maxwell to Duke, 14 Sept. 1916 (TNA, CO 904/23/5).

${ }^{232}$ Moore to General Hutchinson (HQ Irish Command), 24 Oct. 1916 (NLI, Moore papers, MS 10,561/20).

${ }^{233}$ Minutes of special meeting of national committee, 12 Sept. 1916 (ibid., MS 9,239).

${ }^{234}$ Donovan and Kettle to Volunteer companies, 27 Sept. 1916 (ibid., MS 10,545/9); Maxwell to Duke, 29 Sept. 1916 (TNA, CO 904/23/5).

${ }^{235}$ Moore to editor of Irish Times, published on 6 Oct. 1916.

${ }^{236}$ Circular from Donovan and Kettle to Volunteer companies, 16 Oct. 1916 (TNA, CO 904/23/5).

${ }^{237}$ Minutes of meeting of general purpose committee, 17 Oct. 1916 (NLI, Moore papers, MS 9,241); Donovan and Kettle to Volunteer companies, 20 Oct. 1916 (TNA,
} 
such exhortations were tantamount to 'encouraging rebellion'. ${ }^{238}$ Such fears were quickly allayed as Redmond and the IPP leadership abruptly scotched all efforts to reform the Volunteers, attempted to isolate Moore and postponed the Volunteer convention indefinitely.

The disputed Volunteer convention split the National Committee into three discernible factions. The first was headed by Moore and it pressed vainly for a meeting at the earliest opportunity so that direction could be given to the corps. ${ }^{239} \mathrm{He}$ was adamant that the internal affairs of the Volunteers should not be subordinated to the exigencies of party politics. At a meeting on 14 November, the frustrated colonel declared that he would sever his connection with the Volunteers and publicly state his reasons if there was further prevarication. ${ }^{240}$ Though nominally loyal to Redmond and the IPP, a second group wished to see something practical done by way of reorganization to prevent young men drifting towards Sinn Féin. ${ }^{241}$ The third section represented the IPP leadership. Redmond informed the honorary secretaries that a convention would be "fraught with grave mischief, not only to the cause of the Volunteers themselves but to many other causes of national importance'. ${ }^{242}$ To some in this group such as John T. Donovan MP, one of the honorary secretaries, a convention was absurd in view of the fact that there were only thirty affiliated companies and that martial law was still in force..$^{243}$ A decision on the matter was adjourned until a special meeting of the national committee on 19 December when it was expected Redmond would attend. Unable to do so, the IPP leader's stance had hardened. He informed the honorary secretaries that any attempt to contravene military regulations against drilling would be 'fatal' and the holding of a convention would have 'very serious and injurious consequences' for which he could not be responsible. Apropos the Volunteers, Redmond believed 'beyond keeping the organisation as far as is possible in existence, that no active policy is possible for the moment'. 244

CO 904/23/5).

${ }^{238}$ Lord Decies (chief press censor) to private secretary to chief secretary, 25 Oct. 1916 (TNA, CO 904/23/5).

${ }^{239}$ Minutes of special meeting of national committee, 14 Nov. 1916 (NLI, Moore papers, MS 9,239).

${ }^{240}$ Donovan to Redmond, 15 Nov. 1916 (NLI, Redmond papers, MS 15,185).

${ }^{241}$ Ibid.

${ }^{242}$ Redmond to Donovan and Kettle, 31 Oct. 1916 (NLI, Moore papers, MS $10,545 / 9)$. This letter was read at a special meeting of the national committee on 14 Nov. 1916.

${ }^{243}$ Donovan to Redmond, 15 Nov. 1916 (NLI, Redmond papers, MS 15,185).

${ }^{244}$ Redmond to Donovan and Kettle, 15 Dec. 1916, ibid; Minutes of special meeting of national committee, 19 Dec. 1916 (NLI, Moore papers, MS 9,239). 
The IPP leader's ever shrinking authority was underlined by his inability to silence the insurgents on the national committee and in February a motion to hold a convention on Easter Monday 9 April 1917 was carried. ${ }^{245}$ Openly defied, Redmond signalled his intention to stand down as president of the Volunteers. ${ }^{246}$ Far from discouraging a public convention, the authorities actually favoured this development over private meetings of National Volunteers where surreptitious plans might escape police notice. ${ }^{247}$ Permission to stage the convention was granted to Moore by the competent military authority provided the meeting took place indoors without a parade or press publicity and with numbers capped at two hundred. ${ }^{248}$ But at a bruising meeting of the national committee on 20 March 1917, at which a communication was read announcing Redmond's resignation, Moore's efforts to hold a convention were once again frustrated. ${ }^{249}$ Incensed, he moved a condemnatory resolution and, in a letter to the press, denounced the postponement as a violation of the constitution and 'deeply injurious to the movement and to the National cause'. ${ }^{250}$

Moore made one last attempt to force the committee to hold a convention. A meeting of all Dublin officers assembled at headquarters on 22 April and unanimously approved a resolution that a convention be held immediately. A few days later Moore invited National Volunteer officers throughout the country to attend a meeting in the Mansion House on Whit Sunday, 27 May 1917.251 Although ostensibly gathered to discuss the convention, Moore clearly desired a general Volunteer reunion and issued instructions to officers not to prejudice its chances. ${ }^{252} \mathrm{He}$ was warned by the military authorities that any attempt to re-establish an armed force

\footnotetext{
${ }^{245}$ Minutes of special meeting of national committee, 6 Feb. 1917 (NLI, Moore papers, MS 9,239); Donovan to Redmond, 7 Feb. 1917 (NLI, Redmond papers, MS $15,185)$.

${ }^{246}$ Redmond to honorary secretaries INV, 13 Feb. 1917 (NLI, Redmond papers, MS 15,185).

${ }^{247}$ Note by under-secretary, 3 Feb. 1917 (TNA, CO 904/23/5); General R. Hutchinson (HQ Irish Command) to Moore, 7 Mar. 1917 (NLI, Moore papers, MS $10,561 / 20)$.

${ }^{248}$ Hutchinson to Moore, 12 Mar. 1917 (NLI, Moore papers, MS 10,561/20); Minute on proposed convention of delegates from National Volunteers in Dublin on Easter Monday 1917 (TNA, CO 904/23/5).

${ }^{249}$ Minutes of special meeting of national committee, 20 Mar. 1917 (NLI, Moore papers, MS 9,239); Donovan to Redmond, 20 Mar. 1917 (NLI, Redmond papers, MS 15,185).

${ }^{250}$ Moore to editor of the Irish Independent, published on 30 Mar. 1917.

${ }^{251}$ Moore to editor of the Freeman's Journal, published on 1 May 1917.

${ }^{252}$ Circular from Moore to J. Judge, 15 May 1917 (NLI, Moore papers, MS 10,561/18).
} 
would result in proceedings against him under the Defence of the Realm Regulations but they were sufficiently satisfied to allow the meeting to proceed. ${ }^{253}$ By this time, and unknown to Moore, Michael Collins was keen to gain control of National Volunteers' property and funds. Two of his adherents - Laurence Nugent and Tom Cullen - were National Volunteers, at least in name, and played a significant role in steering Moore's efforts. ${ }^{254}$ A preliminary resolution at the May meeting expressed sympathy with 'ancient comrades in arms who lost their lives in the cause of Irish freedom' and demanded the release of internees. A Castlebar correspondent informed Moore that this made a 'profound' local impression. ${ }^{255}$ Three significant resolutions were passed at the meeting, which was attended by about 150 delegates. First, those present were requested to have their companies affiliated by the end of June. Second, if the National Committee did not summon a convention by the first week in July then Moore was instructed to do so by the end of the first week in August. A committee was appointed to aid him. Thirdly, the meeting invited 'all men who belonged to the Volunteers before the split to re-join in friendliness and forgetfulness of the past in a non-party organisation'. ${ }^{256}$

Moore's gravitation towards Sinn Féin was recognized by Henry Duke, the chief secretary, who requested him to establish if Sinn Féin would join the Irish Convention. Moore consulted 'responsible members' of the party and various friends but reported that there was no prospect of Sinn Féin coming on board as nominees of the government. ${ }^{257}$ The party was, however, prepared to examine the proposals of members with broadly sympathetic views, or as Duke termed it, those in the 'outer circle', and it appears to be on this basis that five seats were reserved for 'Sinn Féin'. ${ }^{258}$ At the end of July 1917, after the convention had started its work, Moore's name was briefly considered but then passed over when it was proposed that the vacant Sinn Féin places be filled by co-option. ${ }^{259}$

By this time relations between Moore and the National Volunteers had all but broken down. Moore's patience snapped on 17 July when, he revealed to Monsignor Arthur Ryan, trustee of the National

\footnotetext{
${ }^{253}$ Lieut-Gen Brian Mahon (C-in-C the forces in Ireland) to chief secretary, 17 May 1917 (TNA, CO 904/23/5).

${ }^{254}$ Witness statement of Laurence Nugent (BMH, WS 907, 88-92).

${ }^{255}$ C.W. Ryan to Moore, 1 June 1917 (NLI, Moore papers, MS 10,561/31A).

${ }^{256}$ Freeman's Journal, 28 May 1917; Moore to editor of Evening Herald, published 19 June 1917

${ }^{257}$ Moore to Duke, 8 June and 24 June 1917 (NLI, Moore papers, MS 10,561/10).

${ }^{258}$ Duke to Moore, 26 June, 12 July 1917 (NLI, Moore papers, MS 10,561/10).

${ }^{259}$ R. B. McDowell, The Irish Convention, 1917-18 (London, 1970), 84-5.
} 
Volunteers and a former Gaelic League comrade, 'no inducement could make those who had the controlling influence in the Vol[unteer] s. call a Convention'. ${ }^{260} \mathrm{He}$ argued that as the period of office of the national committee had expired the only remaining authority was the convention which, under the constitution, elected the president, officers and national committee. The honorary secretaries maintained that a meeting would be held only when one hundred companies had affiliated. Moore believed that ordinary Volunteers would regard this precondition as 'a sham demand ... the intention was to squash the Vol[unteer]s and prevent a Convention'. He insisted that if he had 'acted irregularly it was to end an illegality'. ${ }^{261}$

With the connivance of the Irish Volunteer executive, Moore and his followers remained in possession of 44 Parnell Square and, according to police reports, were said to be armed to prevent the Redmondite section retaking the building. ${ }^{262}$ In the event, the Redmondite faction instructed the post office to redirect post to 6 Cavendish Row and disconnect the telephone. It later threatened legal action to recover the deeds of 44 Parnell Square but Moore refused to cooperate. The authorities were understandably worried that the secessionists' arms would be transferred to the Irish Volunteers. It was estimated that between 200 and 250 Italian rifles, 21 Martini Henri rifles, 50.22 rifles and 50,000 rounds of ammunition were stored in 44 Parnell Square. ${ }^{263}$ The police were instructed to seize any weapons removed from the building. ${ }^{264}$ Nugent recalled that the principal objects behind the seizure of No. 44 were to prevent weapons being confiscated by the authorities and to call 'a convention of our own and demand control of the funds and property' from the trustees, Monsignor Ryan and Michael Governey. ${ }^{265}$ Without Moore's knowledge, Nugent and Cullen used the National Volunteers register to contact companies and pack the convention. In the midst of such heady developments Moore gifted his portrait, painted by Walter Osborne, to Dublin's Municipal Gallery of Modern Art, then located on Harcourt Street. ${ }^{266}$

\footnotetext{
${ }^{260}$ Moore to Ryan, 5 Aug. 1917 (NLI, Redmond papers, MS 15,263/3).

${ }^{261}$ Ibid.

${ }^{262}$ Freeman's Journal, 19 and 21 July 1917; DMP Detective Department to chief secretary, 19 and 23 July 1917 (TNA, CO 904/23/5); Witness statement of Laurence Nugent (BMH, WS 907, 112).

${ }^{263}$ Minute by DMP chief commissioner, 1 Aug. 1917 (TNA, CO 904/29/3).

${ }^{264}$ Colonel F.H.G. Scanton (AAG Irish Command) to under-secretary, 4 Aug. 1917 (TNA, CO 904/23/5).

${ }^{265}$ Witness statement of Laurence Nugent (BMH, WS 907, 112-13).

${ }^{266}$ Henry Campbell (town clerk) to Moore, 31 July 1917 (NLI, Moore papers, MS $10,561 / 2)$.
} 
The long deferred convention, at which 176 companies from nineteen counties were represented, was held in the Mansion House on 5 August. The proceedings, over which Moore presided, were conducted in private. ${ }^{267}$ In his address Moore emphasized that "the desire of all is to unite the Volunteers in Ireland as they were united in 1913 and 1914'. ${ }^{268}$ This sentiment was embodied in a resolution affirming allegiance to the original declaration of the Volunteers, advocating reunion, and proposing a general reorganization. A reconciliation committee was appointed to enter negotiations with the Irish Volunteers. Another resolution looked forward to an independent Ireland in which the Volunteers would become the national defence force. ${ }^{269}$ The proposed reunion with the Irish Volunteers greatly alarmed the civil and military authorities. Lieutenant-General Bryan Mahon, the Irish commander-in-chief, deemed the situation 'a matter of extreme importance and danger' and in the interests of 'public safety' ordered the seizure of arms in the possession of the National Volunteers lest they fall into Sinn Féin hands. ${ }^{270}$ This was carried out across the country by the RIC and military on the 14-15 August and an estimated 2,668 rifles were taken up. ${ }^{271}$ The manner of the raid on 44 Parnell Square and the fact that the same order was not applied to UVF arms drew strong criticism from Moore. ${ }^{272}$ Those National Volunteers who remained loyal to Redmond, such as John T. Donovan MP, blamed Moore for precipitating the arms raids. ${ }^{273}$ Moore's conduct during August 1917 led the chief secretary to consider invoking the Defence of the Realm regulations to prohibit him from residing in Ireland. This course was not followed, however, as Mahon believed that it would confer on Moore 'a greater importance than he deserves'. ${ }^{274}$ Spurred into action, the Redmondite section of the National Volunteers held its own convention in the Mansion House on 28 September. Its stance was neatly captured by Arthur Ryan, who informed Moore: 'if I thought that our ranks would be used even indirectly to strengthen the cause of Irish republicanism, I'd sooner see them disbanded. ${ }^{275}$ In their

\footnotetext{
${ }^{267}$ Irish Independent, 6 Aug. 1917; Irish Times, 6 Aug. 1917.

${ }^{268}$ Address by Moore to Volunteer convention, 5 Aug. 1917 (NLI, Moore papers, MS 10,545/9).

${ }^{269}$ Agenda for convention, 5 Aug. 1917 (NLI, Moore papers, MS 10,545/9); Freeman's Journal, 6 Aug. 1917; Irish Times, 6 Aug. 1917.

${ }^{270}$ Bryan Mahon to chief secretary, 8 Aug. 1917 (TNA, CO 904/29/3).

${ }^{271}$ Minute by RIC Inspector-General, 16 Aug. 1917, ibid.

${ }^{272}$ Moore to Mahon, 16 Aug. 1917 (TNA, CO 904/29/3).

${ }^{273}$ Freeman's Journal, 17 Aug. 1917.

${ }^{274}$ Chief secretary to Mahon, 7 Aug. 1917; Mahon to chief secretary, 8 Aug. 1917 (TNA, CO 904/29/3)

${ }^{275}$ Ryan to Moore, 11 Aug. 1917 (NLI, Moore papers, MS 10,561/31A).
} 
report the honorary secretaries aimed a bitter ad hominem parting shot at Moore's 'disloyal attempt to break up the organisation.' 276

In November the DMP detective reviewing a report of a meeting at 44 Parnell Square attended by Moore, Michael Collins and Joseph McGuinness MP observed in the margins: 'the association of Col. Moore with these people is significant'. ${ }^{277}$ When Moore later wrote a history of the Irish Volunteers his account finished with the reunion in 1917. ${ }^{278}$ Events had come full circle although Moore was then no longer a leading figure in the Irish Volunteers, the direction of which had passed to younger and more radical men. Number 44 was also not openly occupied as it had been closed by the authorities. It was, however, used occasionally by the Dublin Brigade during the War of Independence. ${ }^{279}$ When in October 1919 the legal representatives of the trustees of the National Volunteers sought the deeds in order to sell the premises, Moore maintained that the building had been paid for by the Irish people and Irish Americans to train the Volunteers and as that body was now reunited the building reverted to them. No deeds appear to have been handed over. ${ }^{280}$

\section{Secret Dáil envoy to South Africa, 1921}

Though not a first rank activist during the War of Independence, Moore retained the confidence of, and was willing to serve, the underground Dáil. In September 1920 he was appointed chairman of the Dáil commission of enquiry into the Resources and Industries of Ireland which had been established in 1919 and whose members represented business, science and industry. Described as 'not less than a National Economic Council' by its secretary, Darrell Figgis, it travelled the country 'side by side with the fury of war' taking evidence on all aspects of agricultural production, sea fisheries, coal, hydroelectricity and industrial alcohol. ${ }^{281}$ This role may have brought him to the attention of the authorities as his home at 5 Sea View Terrace in Donnybrook was raided on a number of occasions. On the

\footnotetext{
${ }^{276}$ Freeman's Journal, 29 Sept. 1917.

${ }^{277}$ DMP Detective Department to chief secretary, 27 Nov. 1917 (TNA, CO 904/23/5).

${ }^{278}$ Moore's manuscript was rejected by T. Fisher Unwin in early 1922. It was serialized in the Irish Press between January and March 1938 and published in an Irish translation by Liam Ó Rinn: Tús agus fás Óglach na hÉireann, 1913-1917 in 1936.

${ }^{279}$ Witness statement of Nancy Wyse Power (BMH, WS 587, 12).

${ }^{280}$ Patrick Rooney and Co. Solicitors to Moore, 13 Oct. 1919; Moore to Rooney, 18 Oct. 1919; Moore to Arthur Ryan, 19 Nov. 1919 (NLI, Moore papers, MS 10,561/10).

${ }^{281}$ Darrell Figgis, Recollections of the Irish war (London, 1927), 266-7; Memo by Moore, [c. June 1922] (NLI, Moore papers, MS 10,571/7); Arthur Mitchell, Revolutionary government in Ireland: Dáil Éireann, 1919-22 (Dublin, 1995), 83.
} 
night of 29 January 1921, Moore was arrested, despite his protests, for possessing seditious literature. He suffered the indignity of being carried around Dublin in a lorry as a hostage for the safe conduct of the troops. As George Berkeley, who lunched with Moore after his release put it, this was 'a noble recompense for having offered his life a thousand times in the wars of the Empire'. ${ }^{282}$ In an indignant letter to Neville Macready, the general officer commanding-inchief, Moore explained that the seditious material was in fact his post and that "practically every paper dealing with politics or the actions of the authorities, whether true or false, may be described as "seditious". ${ }^{283}$ He was released on 31 January as an act of clemency on account of his age and position but was warned as to his future conduct. Moore's protest that the matter should be investigated fully and that documents be returned to him went unheeded. ${ }^{284}$ No further action was taken as Moore embarked on an intriguing mission as Dáil Éireann's envoy to South Africa.

Seeking international recognition for an Irish republic was a key objective for Sinn Féin. Hence at the inaugural meeting of Dáil Éreann an appeal was issued to the free nations of the world to acknowledge Ireland as a state in her own right and a team, headed by Seán T. Ó Ceallaigh, was dispatched to the Paris peace conference but failed to gain admission. Unfazed by this setback or the so-called British paper wall around Ireland, the Dáil government initiated an expansive campaign to gain international support and influence public opinion at home and abroad. Particular emphasis was placed on providing information for visiting journalists and transmitting political propaganda. The work of the Department of Publicity, the Irish mission in the United States and the Department of Foreign Affairs dovetailed to the extent that Arthur Mitchell deemed foreign affairs 'propaganda under another name'. ${ }^{285}$ Initially the department of foreign affairs concentrated its efforts on Britain, where Art Ó Briain in London played a key role; America, where Éamon de Valera spent eighteen months; Paris, where there had been a Dáil presence since early 1919; and Italy. ${ }^{286}$ From mid-1920 several consuls and diplomatic agents were appointed by the Dáil to various European countries, Russia, South America and the dominions as public, political and press interest in Irish self-government mounted.

\footnotetext{
${ }^{282}$ Witness statement of George Berkeley (BMH, WS 994, 69-70).

${ }^{283}$ Moore to Macready, 4 Feb. 1921 (NLI, Moore papers, MS 10,561/25).

${ }^{284}$ Moore to Macready, 17 Feb. 1921, ibid.

${ }^{285}$ Mitchell, Revolutionary government, 105.

${ }^{286}$ Ibid., 106.
} 
Moore was one of two diplomatic representatives sent to South Africa in April 1921. The other was Patrick J. Little, journalist, lawyer and TD for Dublin Rathmines, who, after three months, moved on to South America. Writing in the Freeman's Journal in 1924, Moore recalled that he had just returned from the funerals in Limerick of George Clancy, mayor of Limerick; Michael O'Callaghan, his predecessor as mayor, and Joseph O'Donoghue - all murdered on 7 March - when he was approached by Oliver St John Gogarty on behalf of the Dáil government. After some reflection, Moore accepted a secret assignment to put the Irish case before General Jan Smuts, who, prior to leaving Europe in 1919, had spoken publicly in favour of Irish independence. ${ }^{287}$ The South African premier was also due to attend the Imperial Conference in London in July 1921 and the colonial angle was one the Dáil government wished to exploit. Moore's name was not unfamiliar to Smuts. They had previously met in London in the home of Alice Stopford Green. Moreover, during the conscription crisis Moore wrote a lengthy and confidential letter to the South African leader in which he revealed his authorship of the controversial letter to the Freeman's Journal in January 1901 on the subject of the Boer War. He asked Smuts to use his influence 'to save my countrymen from the grave disaster of a conscription which will drench the country in blood' and Smuts promised to give the matter every consideration. ${ }^{288}$ Despite requests, Moore was given no specific instructions for his mission. De Valera simply advised that he use his own judgement: 'flattering to my vanity,' Moore later wrote 'but full of danger to me.' ${ }^{289}$ He sailed from Southampton on 2 April and about eighteen days later arrived in Cape Town, where he remained until the end of July 1921. ${ }^{290}$

The ground had been prepared somewhat for the Dáil envoys by the Irish Republican Association. Started about six months before, it published a fortnightly journal The Republic and had about a thousand members in thirteen branches. ${ }^{291}$ In addition to sending a deputation to Smuts before his departure for the Imperial Conference in London, the Irish mission also hoped to raise funds and generally to influence public opinion in South Africa which, if informed at

\footnotetext{
${ }^{287}$ Freeman's Journal, 30 June 1924.

${ }^{288}$ Moore to Smuts, 12 Oct. 1918, Smuts to Moore, 18 Oct. 1918 (NLI, Moore papers, MS 10,561/38).

${ }^{289}$ Freeman's Journal, 30 June 1924.

${ }^{290}$ Note re Irish Republican Government mission to South Africa 1921, n.d. (NLI, Moore papers, MS 8,489/4).

${ }^{291}$ Report by Patrick J. Little, Cape Town, 14 Apr. 1921 (NAI, DE 2/526) in Ronan Fanning, Michael Kennedy, Dermot Keogh and Eunan O'Halpin (eds), Documents on Irish Foreign Policy - (hereafter DIFP) (9 vols, Dublin, 1998-), i, 133.
} 
all about Ireland, was much divided: 'The Dutchmen are with us through hatred of England but they are Calvinistic, very ignorant and prejudiced against Catholics. The Nationalists would like to use the Irish as a stick to beat Smuts with. The Dutch papers accept anything favouring us. The English papers are entirely jingo.' ${ }^{292}$ While composing a statement of Ireland's case, Moore made contact with leading men of every party in South Africa and later recalled that everyone he encountered, even those strongly unionist and imperialist, received him with personal kindness. ${ }^{293} \mathrm{He}$ was more sanguine than Little about Smuts lending support to the Irish cause. Given his experience of the country and acquaintance with Smuts and others, Moore was certainly the better-equipped Irish envoy for this aspect of the mission. He was confident that Smuts would be inclined to help for three reasons: first because the Irish had always helped the Boers; second because of Smuts's support for the freedom of small nations; and third, because of the likelihood that Irish selfgovernment would be advantageous to the British Empire.

These arguments were elaborated by Moore in five well-crafted memoranda prepared for the South African leader on various aspects of the Irish situation, current and historical. ${ }^{294}$ When Moore met Smuts on 1 May his approach was to encourage him 'to advocate freedom for Ireland in as wide an extent as his sympathy and his policy will permit ... He can hardly refuse to go as far as the South African Constitution, though many of his Unionist followers will not like even that'. ${ }^{295}$ In his first memorandum, Moore emphasized that the Irish people sought 'absolute independence' but stressed that the 'immediate object is to secure ... a truce from the devastating war which is damaging England, Ireland, and, in a lesser degree, the Dominions; disgracing the army and ruining the reputation of England throughout the world'. ${ }^{296}$ His second briefing document set out the background historical context of failed constitutional agitation, Easter 1916 and its aftermath, and the rise of Sinn Féin culminating in the 1918 general election triumph. ${ }^{297}$ The third continued the story

\footnotetext{
292 Ibid.

${ }^{293}$ Freeman's Journal, 30 June 1924.

${ }^{294}$ After the interview with Smuts, Moore prepared two further memoranda, one covering Irish history from 1172 to the Act of Union, and another on the Government of Ireland Act (1920).

295 'First report from South Africa' by Maurice Moore, Cape Town, 21 Apr. 1921 (NAI, DFA ES Box 32 File 233) in DIFP, i, 136.

${ }^{296}$ Memorandum by Moore 'No. 1.General Statement for General Smuts', Cape Town, 1 May 1921 (NLI, Moore papers, MS 10,581).

${ }^{297}$ Memorandum by Moore 'No. 2. Cause of the Discontent: First Rebellion of 1916 and Rise of Sinn Féin', Cape Town, 1 May 1921 (NLI, Moore papers, MS 10,581).
} 
up to 1921 and was particularly critical of the British response to the Irish troubles. Moore suggested that Lloyd George

overrated the effect of terrorism and under-rated the courage and tenacity of the Irish people. Even if he had succeeded in his military policy he would only have accumulated a legacy of hate which one day when opportunity occurred, would cause a new rebellion ... such have recurred with unerring regularity during every generation for seven hundred years. Is it not time to end the cycle? ${ }^{298}$

The fourth memorandum dealt with the treatment of prisoners and English propaganda. Moore argued that the conditions of war should be recognized in the treatment of Irish prisoners. 'The English hold that it is murder to kill a soldier or armed policeman in battle, but it is perfectly legitimate to shoot Irishmen not only in battle but at any time, extending their claim to women sitting on their doorsteps or children flying frightened from armed troops.' He did not assert that the conduct of the Volunteers was faultless but believed that 'on the whole, their conduct has been as admirable as that of the Auxiliaries has been disgraceful'. ${ }^{299}$ Moore highlighted the lurid propaganda associated with the Kilmichael ambush and pointed out that of all the murders committed by Crown forces not a single individual was punished by death 'though the Government claim to prove all cases against the Volunteers and have hanged a number, they have never hanged one of their own'. ${ }^{300} \mathrm{He}$ closed by referring to the fabrication by the authorities of an issue of the Irish Bulletin, an act, he argued, that 'exposes the mean refuge to which English propaganda in Ireland resorts to discredit its adversaries'. ${ }^{301}$

The fifth memorandum is the most noteworthy as it addressed in turn two key interlocking issues: proposals for a truce and peace negotiations. Moore opened by stressing that the peoples of both England and Ireland desired peace which was also favoured by the press, with the exception of the unionist Morning Post. He suggested that Lloyd George 'would settle if he were not stopped by Tory diehards ... Only pressure amounting to compulsion will overcome their resistance. The only pressure available now is the

\footnotetext{
${ }^{298}$ Memorandum by Moore 'No. 3. Second Rebellion - 1919, '20, '21', Cape Town, 1 May 1921 (NLI, Moore papers, MS 10,581).

${ }^{299}$ Memorandum by Moore 'No. 4. Shooting of Prisoners', Cape Town, 1 May 1921

(NLI, Moore papers, MS 10,581).

${ }^{300}$ Ibid.

${ }^{301}$ Ibid.
} 
THE CAREER \& CONTRIBUTION OF COL. MAURICE MOORE, 1854-1939 123

Imperial Conference' ${ }^{302}$ Moore dismissed any possibility of reaching a settlement while the conflict continued and cogently presented the dangers of such a course of action. A truce was an essential prerequisite and Moore was adamant that its terms should involve, on one hand, the suspension of the Defence of the Realm Act and martial law and the removal of the Auxiliaries, and, on the other, a bilateral end to hostilities, raids, ambushes and imprisonments. He also called for a 'straightforward, honest, intelligent, soldierly C[ommander]-in-C[hief] of the Forces to be sent to Ireland' but doubted that the government 'would have the good sense to remove Macready although he is already a proved failure'. ${ }^{303}$ In the second part of this memorandum, Moore put forward six broad considerations to prevent future difficulties between Britain and Ireland but stressed from the outset that it was for de Valera and the Dáil to lay down specific terms. The Irish legislature and executive should be free from interference from which it followed that Ireland should be economically and financially independent. Moore's fourth point addressed one of his own preoccupations - the over-taxation of Ireland; his fifth, an older fixation, that Ireland should have her own defence force. Lastly, he proffered insightful advice regarding an oath of fealty to the crown:

\begin{abstract}
it is useless to insist on an oath of allegiance; Sinn Féiners and Volunteers have a very high sense of honour and truth, and will not for all the world prostitute it or act on the theory of mental reservation. This may be wise or unwise but it is part of their character and part of the power which has enabled them to bear horrible punishment, imprisonment, starvation, hanging. It will be wiser to take this into consideration than to ignore the fact; the English will not understand these peculiarities of temperament, but must put up with them; it will pay them better to wait a while for opinion to solidify. ${ }^{304}$
\end{abstract}

In a report to Dublin on 12 May Moore made clear his recognition that Smuts could not advocate a republic for Ireland while opposing one in South Africa. ${ }^{305}$ But neither could he advocate fewer rights

\footnotetext{
${ }^{302}$ Memorandum by Moore 'No. 5(a) Present Position; Proposals for a Truce and a Peace on a Permanent Basis', Cape Town, 1 May 1921 (NLI, Moore papers, MS $10,581)$.

${ }^{303}$ Ibid.

${ }^{304}$ Ibid.

${ }^{305}$ 'Final report May 12, 1921 to the republican government of Ireland' (NLI, Moore papers, MS 10,581).
} 
for Ireland than he claimed for South Africa. Moore reported on Smuts's evolving ideas on the nature of dominion status and the Empire or what Smuts termed the 'Higher Status' of the dominions. As far as Moore could discern, this meant independence from the English parliament and connection with the Empire only through the Crown; this may have inspired de Valera's subsequent external association concept. Moore believed that the dominions were in a stronger position than the US to bring pressure to bear on the British government. He signed off his report on 12 May by claiming: 'all I have said is capable of achievement. I have not written entirely out of my own imagination, but with due deliberation' ${ }^{306}$ Smuts set out for London on 25 May and Moore urged that a Dáil representative be in place to communicate personally with the South African premier, who was 'anxious to know the definite official view on the matters to be settled; and wants someone who can say "yes" or "no". 307 Personally, Moore believed that Smuts was 'very anxious to settle the matter satisfactorily (or as near satisfactorily as possible) for the Irish; though he must not be expected to compromise his own political career'.$^{308}$

Moore's confidence in Smuts was proved correct as he played a starring role in the clandestine diplomatic moves that led to the AngloIrish truce on 11 July 1921. He drafted King George V's speech of reconciliation to the Irish people at the opening of the new Northern Ireland parliament, and was invited by de Valera to Dublin, where he urged Irish nationalists to accept a non-republican constitution for southern Ireland and dominion status. ${ }^{309}$ As Alvin Jackson has argued, for the British government the parallels between their experience in South Africa in 1899-1902 and Ireland were superficially convincing. Indeed the British press drew comparisons between the Boer military leaders and IRA commanders. ${ }^{310}$ On his return to Dublin Moore thanked Smuts for his intervention and looked forward to Ireland obtaining a position not less than the higher status of South Africa. However, Moore presciently warned of 'a strong republican party here, young men fanatically opposed to a King or an Empire ... We 
all sincerely hope that another outbreak may be prevented ... with a constitution so complete that they will be persuaded to peace'. ${ }^{311}$ In late August 1921, de Valera conveyed his 'high appreciation of the excellent work' conducted by Moore in South Africa. His reports were deemed 'very instructive \& contributed considerably in helping the Ministry in the difficult work in hand'. ${ }^{312}$ Moore's response was typically courteous: 'there can be no greater satisfaction than to think that I have been able to fulfil the trust with which I was honoured'. ${ }^{313}$ In October 1921, while recovering from an operation in London, he prepared some briefing notes for the Irish negotiating team on the removal of British troops from South Africa and the transfer of posts to the South African Defence Force. ${ }^{314}$ Moore had one final foray in diplomatic service in the summer of 1922 when he was appointed temporary envoy to Paris from 19 June until 31 July charged with finding suitable premises for the Irish delegation. ${ }^{315}$

\section{Senator, 1922-36}

Weary of war and recognizing the measure of independence gained, Moore accepted the Anglo-Irish Treaty "not because it was a thing admirable in itself but in spite of many imperfections, [he] believed that the widest ... interpretations would be put on its clauses by the Dáil'; in addition, he hoped that it could be improved when the occasion arose. ${ }^{316} \mathrm{He}$ regarded the settlement as offering the Irish Free State the space to consolidate its position. Unsurprisingly, Moore was deeply critical of the IRA convention in March 1922 and the politicization of the army. He claimed that opponents of the Treaty were not genuine republicans because they did not attest to the republican ideal of 'government by the people for the good of the people'. Moore believed that the word republic had been 'turned into a fetish and men are called on to die for the name, [but] not for the reality of freedom' ${ }^{317} \mathrm{He}$ briefly considered standing in the South Mayo-South Roscommon constituency to represent farming, business and professional interests in the election to the third Dáil

\footnotetext{
${ }^{311}$ Moore to Smuts, c. 20 Aug. 1921 (NLI, Moore papers, MS 10,581).

${ }^{312}$ Robert Brennan (secretary for foreign affairs, Dáil Éireann) to Moore, 29 Aug. 1921, ibid.

${ }^{313}$ Moore to Brennan, 30 Aug. 1921, ibid.

${ }^{314}$ Note re Irish Republican Government mission to South Africa 1921, n.d. (NLI, Moore papers, MS 8,489/4).

${ }^{315}$ George Gavan Duffy (minister for foreign affairs) to Moore, 14 June 1922 (ibid., MS 10,583). See also memorandum from Moore to Michael Hayes, Dublin, 25 Aug. 1922 (NAI, DFA ES Paris 1923) in DIFP, i, 499-500.

${ }^{316}$ Moore to unnamed editor, [1922] (NLI, Moore papers, MS 10,571/6); untitled memo by Moore, [1922] (NLI, Moore papers, MS 10,571/6).

${ }^{317}$ Untitled memo by Moore, [1922] (NLI, Moore papers, MS 10,571/6).
} 
in June 1922 on a platform of stable government, industrial and agricultural development, and the extension and completion of land purchase. ${ }^{318}$ In the event, he was not nominated but in December 1922 W. T. Cosgrave appointed him a senator for a nine-year term. ${ }^{319}$ He successfully retained his position at the triennial senate election in November 1931. Until Fianna Fáil's entry to the Dáil in 1927 and Seanad in 1928, the upper house functioned largely on a non-party basis. This allowed senators to adopt a multiplicity of stances on the questions of the day. Moore made contributions on a wide variety of issues but was exercised by matters pertaining to economic development, public finances, the Irish language, local government, and, in particular, land annuities which became his great idée fixe. He was not afraid to take unpopular standpoints.

The introduction of an Electoral Amendment Act in August 1927 requiring all Dáil candidates to pledge, if elected, to take the oath of allegiance induced the political participation of Fianna Fáil and rescued de Valera's party from its self-defeating abstentionist policy. The entry of Fianna Fáil TDs to the Dáil changed the nature of the hitherto largely non-partisan Seanad which now also formed itself into political groupings: Cumann na nGaedheal, Labour Party, Independent Group, Independents and Fianna Fáil. At the triennial elections in 1928 six Fianna Fáil senators were elected with Joseph Connolly serving as leader of this group until the abolition of the house in 1936. As an ardent critic of the land annuities, Moore, unsurprisingly, joined Fianna Fáil and stood unsuccessfully for the party in the election of vice-chairman of the house in December 1928. ${ }^{320}$

As his senate term advanced, Moore became increasingly critical of the Cumann na nGaedheal administration, commenting acidly in February 1928 that it was only a matter of time before it 'dies the death it has earned by its misdeeds'. ${ }^{321}$ Five such misdeeds were singled out by Moore. First, he condemned the government's cavalier attitude towards constitutional amendment. A significant weakness of the 1922 constitution was that under Article 50 it was amendable by ordinary legislation for eight and then sixteen years. The senate, like many second chambers, had little power to prevent this. Second, he objected to the unceasingly heavy-handed approach to law and order.

\footnotetext{
${ }^{318}$ Memo by Moore, [c. June 1922] (NLI, Moore papers, MS 10,571/7); Irish Times, 31 May 1922; Irish Independent, 1 June 1922.

${ }^{319}$ See Donal O'Sullivan, The Irish Free State and its senate: a study in contemporary politics (London, 1940), 89-95.

${ }^{320}$ Ibid., 267-8; Irish Times, 13 Dec. 1928.

${ }^{321}$ Moore to editor of The Nation, 7 Feb. 1928 (NLI, Moore papers, MS 10,571/7).
} 
THE CAREER \& CONTRIBUTION OF COL. MAURICE MOORE, 1854-1939 127

Even in August 1927 when the government, shocked at the callous assassination of Kevin O'Higgins the previous month, introduced a coercive public safety act, Moore was one of the very few to object:

It has been characteristic of Ministers that they seem to think that by unending pressure and abuse of opponents they will get peace. Every year they come to us with a new Coercion Bill, expressing surprise and alarm that similar previous Acts have not had the effect they desired. ${ }^{322}$

Third, Moore advocated the retention of land annuities. He first raised this issue in July 1924 during the third reading of the finance bill and argued that the Government of Ireland Act (1920) gave control of the land annuities to the two Irish governments. On this basis, Moore deemed the $£ 2.9$ million paid over

a nice generous gift. It would be rather a splendid thing if the Minister for Finance had $£ 3,000,000$ in his pockets. How nicely he could balance his accounts. How nicely he could rebuild the Four Courts. How nicely he could set up the whole country if he had that, and we have nothing to do but just to keep these annuities until the country is re-united. ${ }^{323}$

The matter was subsequently brought to the attention of the Public Accounts Committee. ${ }^{324}$ Fourth, Moore condemned the government's handling of the Boundary Commission fiasco in 1925. Lastly, he opposed the nature and terms of the Ultimate Financial Settlement agreed between the Irish and British governments in March 1926.

Following the leaking of the recommendations of the Boundary Commission in November 1925, the governments in Dublin, Belfast and London, in an effort to contain the fallout, agreed to the existing border while granting to Northern Ireland jurisdiction over services which under the Treaty were due to be transferred to a Council of Ireland. The Confirmation of Amending Agreement bill that gave effect to this and absolved the Free State from its liability to service the UK public debt under Article V of the Treaty was rushed through the Dáil on 15 December and debated, at short notice, in the Seanad the following day. Moore made a spirited contribution. He opposed the bill believing that 'the Treaty is practically torn up by this. The

${ }^{322}$ Seanad debates, ix, cols. 223-4 (9 Aug. 1927).

${ }^{323}$ Ibid., iii, no. 14, col. 853 (16 July 1924).

${ }^{324}$ Moore to Public Accounts Committee, 12 Dec. 1925 (NLI, Moore papers, MS $10,560)$. 
bill hands over the lives and liberties of our fellow-countrymen, against their will, to a cruel, bigoted and barbarous faction, from whom at present they are suffering every sort of tyranny, ${ }^{325} \mathrm{He}$ condemned the secret manner and speed with which the agreement was reached and argued that the Treaty would never have been accepted but for Article 12. His trenchant opposition to partition was matched by his disapproval of the magnitude of the financial settlement. Moore contended that Ireland was entitled to her share of the British Empire's assets and owed nothing. He was deeply critical of the government's actions:

We are having six of the thirty-two counties clipped off, an action which is absolutely unconstitutional. Naked we came in and naked we go out. We are in a worse position than we ever expected. We have lost six counties and $£ 5,000,000{ }^{326}$

In the event the bill was passed by the house by 35 votes to 7 with Moore in the minority.

Opposition to the Boundary Settlement occasioned a minor secession from the Cumann na nGaedheal party led by William Magennis, professor of metaphysics at UCD and TD for the National University of Ireland. In January 1926 he founded the short-lived Clann Éireann party which opposed partition, supported the abolition of the oath of allegiance, advocated lower taxes and the fostering of Irish agriculture and Irish industries, proposed the reorganization of government departments, and promoted national culture and censorship. ${ }^{327}$ The party drew to its ranks just three sitting TDs (Magennis, Pádraic Ó Máille and Christopher Byrne), Senator Moore and a handful of former TDs such as Patrick McCartan and Seán Gibbons. ${ }^{328}$ Ultimately, the venture proved a political lemon. The party nominated eight candidates at the June 1927 election but seven lost their deposits and the party won just $0.5 \%$ of the vote. ${ }^{329}$ When Fianna Fáil entered the Dáil in August 1927 Clann Eireann became superfluous and disappeared. Magennis, who had lost his seat, later returned as a Fianna Fáil senator. ${ }^{330}$

${ }^{325}$ Seanad debates, vi, col. 165 (16 Dec. 1925).

${ }^{326}$ Ibid., col. 180.

327 'The programme of Clann Éireann' (NLI, Moore papers, MS 10,560).

${ }^{328}$ Irish Times, 26 Jan. 1922.

${ }^{329}$ On Clann Eireann see Michael Gallagher, Political parties in the Republic of Ireland (Manchester, 1985), 99-100; John Coakley, 'Minor parties in Irish political life, 1922-1989', The Economic and Social Review, 21:3 (April 1990), 276, 279.

${ }^{330}$ See Marie Coleman, 'Magennis, William' in $D I B$ [http://dib.cambridge.org/ viewReadPage.do? articleId=a5338, accessed 7 Apr. 2014]; O'Sullivan, Irish Free 
The Ultimate Financial Settlement set out the terms of a range of liabilities owed by the Irish Free State. The largest obligations were the annuities accruing under the various Irish land acts between 1891 and 1909, which the Irish government undertook to pay in full, and a charge of seventy-five per cent of the pensions and compensation allowances payable to former members of the RIC. ${ }^{331}$ When the white paper came before the Seanad in December 1926, Moore was fiercely critical of the agreement and of Ernest Blythe, minister for finance. He moved a motion that the agreement was 'prejudicial to the financial stability of the Irish Free State and will, if ratified, prove to be an excessive burden on Irish taxpayers'. ${ }^{332}$ The debate proposed by Moore was curtailed due to the absence of a quorum; a suggestion to refer the matter to a special committee of the Seanad was defeated. ${ }^{333}$

Moore argued that the land annuities should be regarded as part of the public debt of the UK and on that basis the Treaty absolved the Free State from that share of the debt. From this point onwards he zealously took up his cudgel against land purchase annuities in the press, in the upper house and as a stump speaker. Although Peadar O'Donnell inspired the anti-annuity agitation, Moore too 'was an energetic evangelist in relation to the annuities issue' but was far more moderate than the socialist-republican O'Donnell. ${ }^{334}$ In a 48-page pamphlet, British plunder \& Irish blunder, published in 1928 and written at the request of Clann Éireann, Moore set out the legal, economic and moral case against the repayments. ${ }^{335} \mathrm{He}$

State, 183.

${ }^{331}$ Heads of the Ultimate Financial Settlement between the British government and the government of the Irish Free State, London, 19 Mar. 1926 (NAI, DT S4730A) in DIFP, ii, 561-3.

${ }^{332}$ Seanad debates, viii, col. 12 (15 Dec. 1926).

333 Irish Times, 16 Dec. 1926.

${ }^{334}$ Richard English, Radicals and the republic: socialist republicanism in the Irish Free State, 1925-1937 (Oxford, 1994), 93. Much has been written on O'Donnell and the land annuities, see Peadar O'Donnell, There will be another day (Dublin, 1963); Michael McInerney, Peadar O'Donnell: Irish social rebel (Dublin, 1974), 121-31; Peadar O'Donnell, Monkeys in the superstructure: reminiscences of Peadar O'Donnell (Galway, 1986), 21-8; English, Radicals, 86-95; Peter Hegarty, Peadar O'Donnell (Cork, 1999), 163-6, 175-9; Donal Ó Drisceoil, Peadar O'Donnell (Cork, 2001), 44-50; Timothy M. O’Neil, 'Handing away the trump card? Peadar O'Donnell, Fianna Fáil, and the non-payment of Land Annuities campaign, 1926-32, New Hibernia Review 12:1 (2008), 19-40.

${ }^{335}$ See also 'Short notes on the Irish land purchase annuities, how they originated and the present position' (NLI, Moore papers, MS 10,560). British plunder and Irish blunder or the story of the land purchase annuities was printed and published by the Gaelic Press Ltd., 21 Upper Liffey Street, Dublin; 5,000 copies of the first edition of the pamphlet and 3,000 copies of the second were printed and priced $3 d$., see William Balfe (managing director) to Moore, 18 Aug. 1928 (NLI, Moore papers, MS 10,560). 
circulated this privately to prominent individuals and newspapers and also asked O'Donnell to serialize it in An Phoblacht. ${ }^{336}$ Moore's agitation offered O'Donnell a means of broadening his campaign and a conduit to Fianna Fáil. A national 'No Tribute' campaign was launched on 14 February 1928 at a meeting in the Rotunda chaired by Moore. ${ }^{337}$ It became clear to O'Donnell and Moore that 'it would greatly help us in the countryside if we could bring Fianna Fáil TDs on to our platform there' ${ }^{338}$ The issue was taken up by Fianna Fáil at its ard-fheis that year and it subsequently became a key criticism of the government and a central plank in its 1932 election manifesto. With the encouragement of Seán Lemass, Moore assembled facts concerning the Ultimate Financial Settlement with a view to having them examined by Fianna Fáil's legal and financial experts. ${ }^{339}$

Both before and after joining Fianna Fáil, Moore was, by his own admission, an unlikely champion of the independence of the Seanad, and from the late 1920s called for its reform rather than abolition. He supported, as did the majority of the house, a proposal in early 1927 to allow senators to be appointed members of the executive council, something ultimately blocked by the Dáil. ${ }^{340}$ In a letter to the editor of The Nation, he drew a distinction between the selection of members of the Seanad and its purpose in a bicameral legislature: 'Yet, whatever may have been its demerits owing to the manner of its selection, I can vouch for the fact that it has been a far more independent and a far more national body than the Dáil. ${ }^{341} \mathrm{He}$ gave several examples of where the Seanad played an important role in highlighting contradictions, inconsistencies and defects in proposed legislation. For example, almost one hundred amendments to the Local Government bill of 1925 were suggested by the upper house and accepted by the government and the Dáil. Moore also highlighted the important role played by the Seanad in advancing the Irish language, the Irish Manuscripts Commission, the closure of public houses on St Patrick's Day and, of course, the fight against land annuities. ${ }^{342}$ True to form he voted against the abolition of the house in June $1934 .{ }^{343}$ Deeming the Seanad a practical obstacle to his authority, de Valera abolished it in May 1936.

\footnotetext{
${ }^{336}$ O'Donnell, There will be another day, 79; Ó Drisceoil, O'Donnell, 48.

${ }^{337}$ Speech by Moore at Rotunda, 14 Feb. 1928 (NLI, Moore papers, MS 10,560); English, Radicals, 93; Hegarty, O'Donnell, 175.

${ }^{338}$ O'Donnell, There will be another day, 89.

${ }^{339}$ Lemass to Moore, 15 Oct. 1929 (NLI, Moore papers, MS 10,561/22).

${ }^{340}$ O’Sullivan, Irish Free State, 203-206.

${ }^{341}$ Moore to editor of The Nation, 7 Feb. 1928 (NLI, Moore papers, MS 10571/7).

${ }^{342}$ Ibid.

${ }^{343}$ Seanad debates, xviii, cols. 1526-7 (1 June 1934).
} 
THE CAREER \& CONTRIBUTION OF COL. MAURICE MOORE, 1854-1939 131

\section{The destruction of Moore Hall}

Moore's public role as a Free State senator was not without significant personal loss. On 1 February 1923 Maurice, in Dublin, and George, in London, received a short and stark telegram from James Reilly, caretaker of Moore Hall: 'Moorehall house burned down last night nothing saved.' ${ }^{344}$ This attack was part of an orchestrated campaign by the anti-Treaty IRA against the property of Free State senators. In January and February 1923 the houses of thirty-seven senators were razed to the ground, including, among others, the famous Renvyle House in County Galway owned by Oliver St John Gogarty, George Moore's one time neighbour in Ely Place, and Senator Sir Bryan Mahon's Mullaboden House near Ballymore Eustace, County Kildare. ${ }^{345}$ Reilly wrote a lengthy letter on 6 February describing how an armed party arrived on the night of 31 January and paid little heed when he explained that Moore Hall did not belong to Colonel Moore. He was able to release the livestock and felt 'as one does when standing by the open grave of a very dear friend' as he helplessly watched the roof fall in. There was, he wrote, 'absolutely nothing left but the walls, not a vestige of glass, timber or even plaster from the ground floor up'. ${ }^{346}$ This misfortune deeply affected both George and Maurice, who in different ways venerated the ancestral home. The former believed he could never set foot in Ireland again. Writing to his son, Maurice (Rory), in Wyoming, Maurice was more stoical:

It was certainly a very hard blow to bear to think of all the associations of one's youth, one's ancestors and one's children swept away and gone irrevocably for ever. One has to bear these afflictions as best one can; they have come to numbers of other people, not only in this country but in other lands. ${ }^{347}$

The destruction of Moore Hall and the advent of his seventieth birthday spurred Moore to make a final attempt at reconciliation with George. On Christmas Day 1924 he wrote: 'I forgive you any injury by word or deed you may have done me, and I am sorry for any word or deed by which I have caused you pain.' ${ }^{348}$ The novelist informed Maurice that he had 'never done him any wrong, my conscience is

\footnotetext{
${ }^{344}$ James Reilly to Moore, 1 Feb. 1923 (NLI, Moore papers, MS 8,489/2).

${ }^{345}$ See Michael Hopkinson, Green against green: the Irish Civil War (Dublin, 2004), 195.

${ }^{346}$ Hone, Moores of Moore Hall, 264-5.

${ }^{347}$ Ibid., 266.

${ }^{348}$ Moore to George Moore, 25 Dec. 1924 (NLI, Maurice and George Moore, MS 4,894).
} 
quite clear, and, as the past cannot be undone, there can never be any real forgiveness' ${ }^{349}$

The subsequent history of Moore Hall was luckless. George Moore sought compensation to the tune of $£ 25,000$ for the loss of the building and its contents but received only a third of this sum. ${ }^{350}$ He later sold the demesne to the Congested Districts Board. His brother harboured aspirations to rebuild Moore Hall and purchased the ruin and about 300 acres of the townland, including the islands on the lake, for $£ 1,300 .{ }^{351}$ This was willed to his son with whom he conferred about the house. Three developments scuppered these plans. The first was the American depression and sustained drought in Wyoming which ensured that Rory had little prospect of returning to Mayo during his father's lifetime. ${ }^{352}$ The second was the mean-spirited decision of George Moore, who died in January 1933 leaving an estate of $£ 80,000$, to omit Maurice and his son from his will. Lastly, Moore lost his senator's salary of $£ 350$ per annum in 1936, though he was subsequently nominated a senator by de Valera in March 1938 in the redevised Seanad. ${ }^{353}$ Father and son now abandoned plans to restore Moore Hall, which was sold to a timber merchant.

\section{Conclusion}

Active into his dotage, Moore died at the age of eight-five on 8 September 1939 and his remains were interred in the family burial place at Kiltoom. Trusting and open by nature and a man of palpable sincerity, steadfastness and bonhomie, Moore was in some ways a figure ripe for manipulation by more selfish and calculating men. He was certainly a great and at times impetuous collector of enthusiasms. So prolific were his interests that the results were inevitably uneven. In tracing the arc of Moore's career, his commitment to the development of Ireland remains a constant compass point, whether in the realm of Irish culture, self-government, economics or an indigenous defence force. His patriotism was indefatigable. Moore's energetic involvement in the Gaelic League and the Volunteer movement, his efforts to seek a reprieve for Casement, his pivotal secret mission to South Africa in 1921 and his vigorous agitation against land annuities emboss a noteworthy but under-appreciated contribution to Irish nationalism. This is still more remarkable when one considers that Moore did not participate in the 1916 Rising during which

\footnotetext{
${ }^{349}$ George Moore to Maurice Moore, 5 Jan. 1925 cited in Hone, George Moore, 396.

${ }^{350}$ Hone, Moores of Moore Hall, 266-7.

${ }^{351}$ Ibid., 269.

${ }^{352}$ Ibid., 272-5.

${ }^{353}$ Irish Times, 1 Apr. 1938.
} 
THE CAREER \& CONTRIBUTION OF COL. MAURICE MOORE, 1854-1939 133

he was technically on the British side. That this did not preclude subsequent acceptance into the Sinn Féin tent was facilitated by Moore's nationalist track record, his remarkable ability to generate a rapport with a wide cast of people and his innocuous status as a second rank activist. And yet there are few personalities during the Irish Revolution that match Moore's adaptability and longevity. The colonel could have enjoyed a quiet and conventional retirement from the army after 1906. But his professional training, sense of patriotic duty and the legacy of his father committed him to public service in the national interest. The seriousness of his commitment to Ireland did permit a pragmatism and prescience be it in his principled clash with Archbishop Healy over the matriculation question, sensing the changed political condition of Ireland after the Rising or, as his reports from South Africa in 1921 indicated, recognizing the limits of Ireland's claims to independence. In a particularly apposite obituary in the Irish Times, Quidnunc described him as being without malice, liked and trusted by all parties and sections ... He belonged to the nation and will be mourned by it' ${ }^{3}{ }^{354}$ This was a fitting testament to an intriguing Irish nationalist.

${ }^{354}$ ‘Irishman’s Diary', Irish Times, 12 Sept. 1939. 
